\title{
BIODEGRADATION POTENTIAL OF CHLORINATED SOLVENTS IN GROUND WATER AT THE NAVAL SURFACE WARFARE CENTER, LOUISVILLE, KENTUCKY, JULY 1999 TO FEBRUARY 2000
}

Water Resources Investigations Report 01-4242

Prepared in cooperation with the SOUTHERN DIVISION NAVAL FACILITIES ENGINEERING COMMAND 


\section{Biodegradation Potential of Chlorinated Solvents in Ground Water at the Naval Surface Warfare Center, Louisville, Kentucky, July 1999 to February 2000}

By Don A. Vroblesky, Paul M. Bradley, Matthew D. Petkewich, and Clifton C. Casey

\section{U.S. Geological Survey}

Water-Resources Investigations Report 01-4242

Prepared in cooperation with the

SOUTHERN DIVISION NAVAL FACILITIES ENGINEERING COMMAND

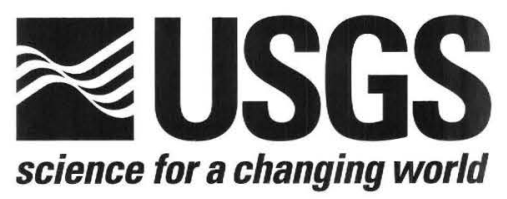

Columbia, South Carolina 


\title{
U.S. DEPARTMENT OF THE INTERIOR \\ GALE A. NORTON, Secretary
}

\author{
U.S. GEOLOGICAL SURVEY \\ Charles G. Groat, Director
}

Use of firm, trade, and brand names in this publication is for descriptive purposes only and does not constitute endorsement by the U.S. Geological Survey

For additional information write to:

District Chief

U.S. Geological Survey

Stephenson Center - Suite 129

720 Gracern Road

Columbia, SC 29210-7651
Copies of this report can be purchased from:
U.S. Geological Survey
Branch of Information Services
Box 25286
Denver, CO 80225-0286
888-ASK-USGS

Additional information about water resources in South Carolina is available on the World Wide Web at http://sc.water.usgs.gov 


\section{CONTENTS}

Abstract fow

Introduction .

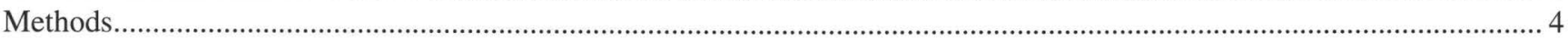

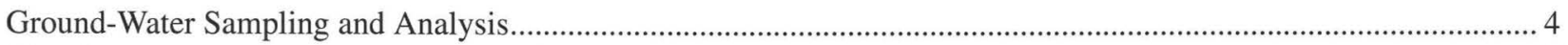

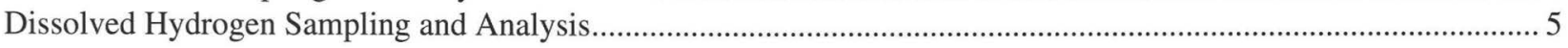

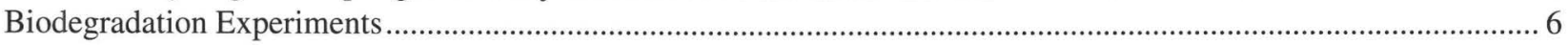

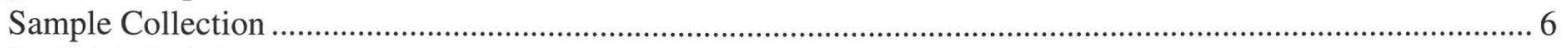

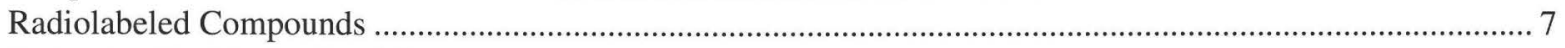

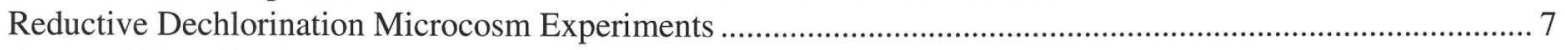

Acetate Mineralization Microcosm Experiments....................................................................................... 7

Methylotrophic Cometabolism Microcosm Experiments ............................................................................... 8

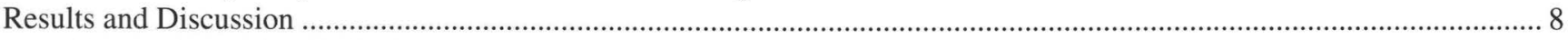

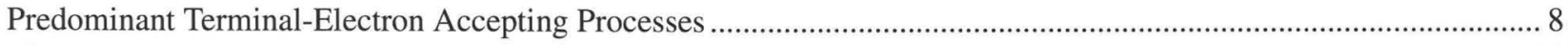

Biodegradation Potential of Chlorinated Solvents at the Station....................................................................... 15

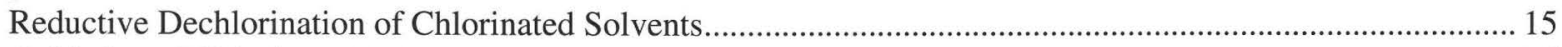

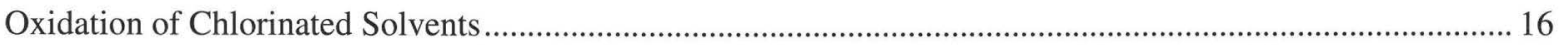

Potential for Chlorinated Solvent Biodegradation in the Bedrock Aquifer if Chlorinated-Solvent

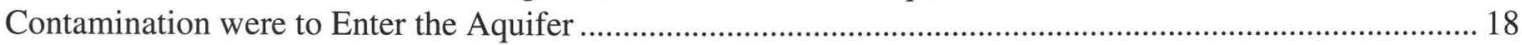

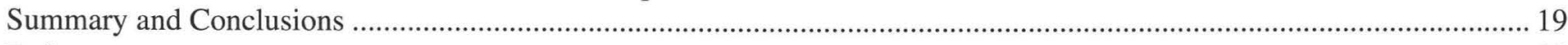

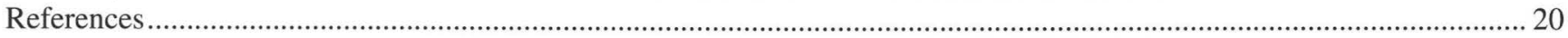

Figures

1. Map showing location of wells and ground-water elevations in the overburden aquifer, Naval Surface Warfare

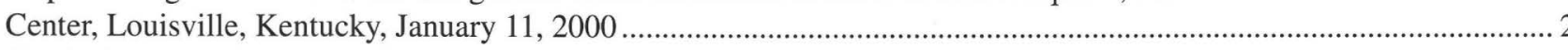

2. Graph showing percentage of carbon-14 radiolabeled carbon dioxide recovery in microcosms of sediment collected from the overburden aquifer near well 1-NEC-MW34-P, Naval Surface Warfare Center, Louisville, Kentucky, January 2000

Tables

1. Construction information and sample-collection date for wells, Naval Surface Warfare Center, Louisville, Kentucky.....

2. Volatile organic compound concentrations in ground water, September 1999 and January-February 2000, and historical sampling results, Naval Surface Warfare Center, Louisville, Kentucky.....

3. Inorganic properties, organic acids, and dissolved gases in ground water from the overburden and bedrock aquifers and the shale confining zone, September 1999, Naval Surface Warfare Center, Louisville, Kentucky......

4. Inorganic properties and dissolved gases in ground water from the overburden aquifer, January-February 2000, Naval Surface Warfare Center, Louisville, Kentucky.

5. Final percentage recovery of carbon 14 radiolabel in microcosms of overburden material from near well 1-NEC-MW34-P, Naval Surface Warfare Center, Louisville, Kentucky 
Conversion Factors

\begin{tabular}{rcl}
\hline Multiply & By & To obtain \\
\hline & Length & \\
inch (in.) & 25.4 & millimeter \\
foot (ft) & 0.3048 & meter \\
mile (mi) & 1.609 & kilometer \\
& & \\
& Area & \\
acre & 0.4047 & hectare \\
& 2.590 & square kilometer \\
& & \\
square mile (mi $\left.{ }^{2}\right)$ & Volume & \\
gallon (gal) & 3.785 & liter \\
& & \\
& Flow & \\
& 0.3048 & meter per day \\
foot per day (ft/d) & 0.3048 & meter per year \\
foot per year (ft/yr) & r &
\end{tabular}

Temperature: In this report, temperature is given in degrees Celsius $\left({ }^{\circ} \mathrm{C}\right)$, which can be converted to degrees Fahrenheit $\left({ }^{\circ} \mathrm{F}\right)$ by the following equation:

$$
{ }^{\circ} \mathrm{F}=\left(9 / 5 \times \mathrm{C}^{\circ}\right)+32
$$

Sea level: In this report, "sea level" refers to the National Geodetic Vertical Datum of 1929 (NGVD of 1929) - a geodetic datum derived from a general adjustment of the first-order level nets of the United States and Canada, formerly called Sea Level Datum of 1929.

Chemical concentration: In this report, chemical concentration in water is expressed in metric units as milligrams per liter $(\mathrm{mg} / \mathrm{L})$ or micrograms per liter $(\mu \mathrm{g} / \mathrm{L})$.
Additional Abbreviations and Acronyms

\begin{tabular}{rll} 
BRAC & Base Realignment and Closure program \\
$\mathrm{DO}$ & dissolved oxygen \\
${ }^{14} \mathrm{C}$ & carbon 14 \\
$\mathrm{H}^{14} \mathrm{CO}_{3}$ & carbon 14 radiolabeled bicarbonate \\
${ }^{14} \mathrm{CO}_{2}$ & carbon 14 radiolabeled carbon dioxide \\
${ }^{14} \mathrm{CH}_{4}$ & carbon 14 radiolabeled methane \\
$\mathrm{dpm}$ & disintegrations per minute \\
$\mathrm{Fe}(\mathrm{II})$ & ferrous iron \\
$\mathrm{Fe}(\mathrm{III})$ & ferric iron \\
$\mathrm{GC} / \mathrm{FID}$ & gas chromatography with flame ionization \\
& detection \\
$\mathrm{GC} / \mathrm{MS}$ & gas chromatography with mass spectrometry \\
$\mathrm{GC} / \mathrm{TCD}$ & gas chromatography with thermal \\
& conductivity detection \\
$\mathrm{H} \mathrm{H}_{2}$ & dissolved hydrogen \\
$\mathrm{LDPE}$ & low-density polyethylene \\
$\mu \mathrm{CCi}$ & microcuries \\
$\mu \mathrm{g} / \mathrm{L}$ & microgram per liter \\
$\mathrm{mg} / \mathrm{L}$ & milligram per liter \\
$\mathrm{mL}$ & milliliter \\
$\mathrm{mL} / \mathrm{min}$ & milliliter per minute \\
$\mathrm{mCi} / \mathrm{mmole}$ & millicuries per millimole \\
$\mathrm{MTBE}$ & methyl-tert-butyl ether \\
$\mathrm{NSWC}$ & Naval Surface Warfare Center \\
$\mathrm{nM}$ & nanomoles per liter \\
$\mathrm{psi}$ & pounds per square inch \\
$\mathrm{GC} / \mathrm{GRD}$ & radiometric detection gas chromatography \\
$\mathrm{TEAP}$ & terminal electron-accepting process \\
$\mathrm{PCE}$ & tetrachloroethene \\
$\mathrm{TCE}$ & trichloroethene \\
$\mathrm{USGS}$ & U.S. Geological Survey \\
& volatile organic compound \\
\hline
\end{tabular}




\title{
Biodegradation Potential of Chlorinated Solvents in Ground Water at the Naval Surface Warfare Center, Louisville, Kentucky, July 1999 to February 2000
}

\author{
By Don A. Vroblesky ${ }^{1}$, Paul M. Bradley ${ }^{1}$, Matthew D. Petkewich ${ }^{1}$, \\ and Clifton C. Casey ${ }^{2}$
}

\section{ABSTRACT}

The U.S. Geological Survey, in cooperation with the U.S. Department of the Navy, Southern Division Naval Facilities Engineering Command, investigated the potential for biodegradation of chlorinated solvents in ground water at the Naval Surface Warfare Center (also known as the Naval Ordnance Station, or the station), Louisville, Kentucky. The subsurface down to at least 100 feet at the station is characterized, from shallowest to deepest, by overburden deposits, a shale layer, and limestone. In general, all of the strata are poorly permeable. The permeable zones of the overburden and the limestone make up the overburden aquifer and the bedrock aquifer, respectively. Observed concentrations of redox-sensitive solutes suggest that the predominant anaerobic terminal electron accepting process in the overburden aquifer can shift between iron reduction and sulfate reduction, possibly as a result of rainfall-induced oxidation events. Daughter-product concentrations and laboratory experiments indicate that a variety of mechanisms, including reductive dechlorination and cometabolic oxidation, appear to be actively

\footnotetext{
${ }^{1}$ U.S. Geological Survey, Columbia, S.C.

${ }^{2}$ Southern Division Naval Facilities Engineering Command, Charleston, S.C.
}

degrading the chlorinated solvents in the overburden aquifer in the northeastern part of the station. However, the apparent lack of daughter products, comparatively low concentrations of methane, ethene, and ethane, relatively low concentrations of dissolved inorganic carbon, and aerobic conditions suggest that trichloroethene is not being significantly biodegraded in the northwestern part of the station near well 1-NW-MW24-P. Laboratory experiments suggest that if chlorinated solvents were to enter parts of the bedrock aquifer similar to the tested zones, the microbial population would not immediately begin to degrade the contaminants, but might proceed following an acclimation period. Because the microbial testing in the bedrock aquifer was done on material recovered from poorly permeable horizons, the results may not be representative of more permeable parts of the bedrock aquifer.

\section{INTRODUCTION}

Ground-water contamination by chlorinated solvents and petroleum hydrocarbons is present at the Naval Surface Warfare Center (NWSC), referred to as the Naval Ordnance Station, or the station, Louisville, Ky. (fig. 1). The station is part of the U.S. Department of Defense Base Realignment and Closure (BRAC) program. The station is located on approximately 144 acres within the southern limits of Louisville, Jefferson 


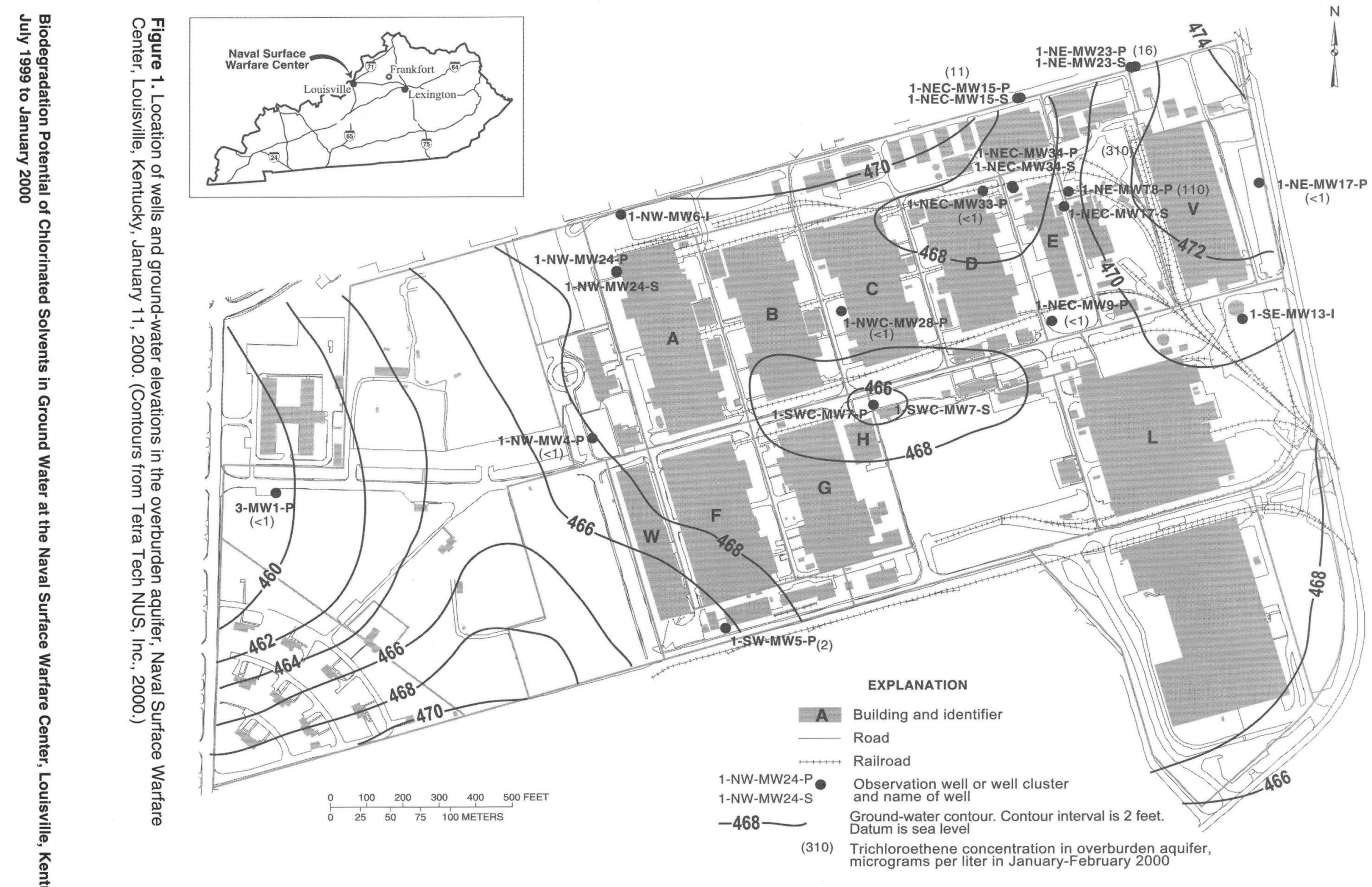


County, Ky. The station is approximately $7 \mathrm{mi}$ south of downtown Louisville, and approximately $1 \mathrm{mi}$ west of Louisville International Airport.

Since 1941, the station has manufactured, overhauled, and produced weapons systems needed by combat vessels of the U.S. Navy. Various hazardous chemicals, including petroleum hydrocarbons, have been released to the soil and ground water as a result of past disposal activities and accidental spills. The sources and extent of ground-water plumes are not yet defined for the station because numerous buildings limit the locations suitable for well installations. The U.S. Geological Survey (USGS), in cooperation with the U.S. Department of the Navy, Southern Division Naval Facilities Engineering Command, investigated the probable mechanisms of ground-water chlorinatedsolvent biodegradation at the station as part of the database used to determine whether natural attenuation can significantly contribute to contaminant containment. The purpose of this report is to discuss the chlorinatedsolvent biodegradation potential in the northern part of the station and to discuss probable biological mechanisms involved in the degradation.

The site hydrogeology has been extensively investigated by consultants and the U.S. Geological Survey (Charles J. Taylor, 1996, U.S. Geological Survey, written commun.). Unless otherwise noted, all information contained in this section is derived from Tetra Tech NUS, Inc. (2001). Three major lithologic rock types characterize the subsurface down to at least $100 \mathrm{ft}$ at the station. From shallowest to deepest they are overburden deposits, a shale layer, and limestone. In general, all of the strata are poorly permeable. The overburden deposits and limestone make up the overburden aquifer and the bedrock aquifer, respectively. The shale layer acts as a hydraulic confining zone.

The shallow overburden deposits range in thickness from about $7 \mathrm{ft}$ in the eastern and northeastern parts of the station to about $30 \mathrm{ft}$ in the western and southwestern parts. The overburden consists of clay to silty clay. A low average hydraulic gradient $(0.0022 \mathrm{ft} / \mathrm{ft})$ and a slug-test-derived horizontal hydraulic conductivity of approximately $1.6 \mathrm{ft} / \mathrm{d}$ imply that the groundwater seepage velocity is about $0.009 \mathrm{ft} / \mathrm{d}$ (assumed porosity of 0.39 ).

In general, ground water in the overburden aquifer enters the station from the north, south, and east, and exits the station to the west and southwest (fig. 1). A hydraulic depression in the center of the station centered at well 1-SWC-MW7-P is consistent over time and based on several wells, implying that the head measurements indicate a downward movement of water near that well. However, uncertainty remains in the interpretation of downward water movement near well 1-SWC-MW7-P because the apparent impermeability of the open interval in adjacent bedrock well 1-SWC-MW7-S makes interpretation of the vertical hydraulic gradient unreliable and because substantial water losses recently realized in the subsurface watersupply lines at the station may have locally affected the distribution of water levels in the overburden aquifer (Kenneth Cotrell, Tetra Tech NUS, oral commun., 2001).

The shale layer, averaging about $10 \mathrm{ft}$ thick where present, underlies the overburden material in most places at the station; however, it is locally absent in the extreme western and southwestern areas.

Although no aquifer tests were done in the shale, the lithology, sparseness of fractures, and literature values for hydraulic conductivity suggest a seepage velocity of about $0.12 \mathrm{ft} / \mathrm{yr}$, or $0.003 \mathrm{ft} / \mathrm{d}$ (Tetra Tech NUS, 2001). Thus, the shale layer appears to function as a confining unit. Although at least three excavations during the operation of the station may have breached the shale and potentially connected the overburden with the bedrock aquifers, water-level data in those areas are reported to show no evidence of hydraulic exchange through the clay.

Limestone underlies the shale and overburden and makes up the bedrock aquifer. Although fractures are present in the bedrock aquifer, most of these do not appear to transmit water. Solution cavities, typically less than $0.25 \mathrm{in}$. in size, are present in a 1- to 5 -ft-thick vuggy zone of moldic porosity in the upper part of the bedrock aquifer approximately $1 \mathrm{ft}$ below the shale contact; but, colloidal borescope measurements in the wells showed that the porsosity is not interconnected enough to transmit water (Aqua VISION, 1999). Using packers, aquifer tests in boreholes in the bedrock aquifer showed the average horizontal hydraulic conductivity to be about $0.0024 \mathrm{ft} / \mathrm{d}$ in flowing zones. Non-flowing zones constituted almost half of the tested zones.

Chlorinated solvents are present in the overburden aquifer in some areas of the station. These areas include areas along the northern boundary of the station and near buildings D and E, as well as in the northwestern part of the station near building A (fig. 1). Following the field work for this investigation, additional ground-water contamination was identified in the southwestern part of the station near buildings $F$ and $G$ 
(TetraTech NUS, 2001). Because the contamination near buildings $\mathrm{F}$ and $\mathrm{G}$ was not part of this investigation, it is not discussed further in this report. Chlorinated solvents were not found in the shale layer or in the bedrock aquifer.

Free-phase petroleum was found in the bedrock aquifer at several locations at the facility, as well as at Auburndale, approximately $1.5 \mathrm{mi}$ south of the facility (Charles J. Taylor, U.S. Geological Survey, written commun., 1996). Hydrocarbon characterization (fingerprinting) showed the petroleum to be crude oil (Environmental Liability Management, Inc., 1999) and, therefore, probably not related to station activities.

\section{METHODS}

A variety of methods were used to conduct this investigation. Methods discussed in the following sections were used to sample and analyze ground water and dissolved hydrogen $\left(\mathrm{H}_{2}\right)$ and to conduct laboratory experiments examining various biodegradation aspects.
Ground-water samples were collected to determine the predominant terminal electron-accepting process (TEAP) and the concentrations of contaminants and daughter products. Biodegradation experiments in laboratory microcosms were conducted to evaluate the potential for trichloroethene (TCE) degradation in the shallow overburden aquifer, to elucidate probable degradation mechanisms, and to evaluate the potential for TCE degradation in the bedrock aquifer if contaminants were to migrate there.

\section{Ground-Water Sampling and Analysis}

Ground water was sampled for volatile organic compounds (VOCs) and redox-sensitive solutes from selected monitoring wells at the station (fig. 1, table 1). Samples were collected by the USGS from 9 wells in September 1999. These included 4 wells in the overburden aquifer, one well in the shale, and four wells in the bedrock aquifer. Tetra Tech NUS (2001) collected additional data from several wells during JanuaryFebruary 2000. Data from 16 of the wells used in the

Table 1. Construction information and sample-collection date for wells, Naval Surface Warfare Center, Louisville, Kentucky

[Well depth is in feet below top of casing; NA, not applicable]

\begin{tabular}{|c|c|c|c|c|c|}
\hline \multirow[b]{2}{*}{ Well number } & \multirow[b]{2}{*}{ Depth } & \multirow{2}{*}{$\begin{array}{c}\text { Well } \\
\text { diameter } \\
\text { (inches) }\end{array}$} & \multirow{2}{*}{$\begin{array}{c}\text { Screen } \\
\text { length } \\
\text { (feet) }\end{array}$} & \multicolumn{2}{|c|}{ Sample-collection date } \\
\hline & & & & $\begin{array}{c}\text { September } \\
1999\end{array}$ & $\begin{array}{c}\text { January- } \\
\text { February } 2000\end{array}$ \\
\hline \multicolumn{6}{|l|}{ Overburden aquifer } \\
\hline 3-MW1-P & 29.9 & 2 & 5 & & $\mathrm{X}$ \\
\hline 1-NW-MW4-P & 10.9 & 2 & 3 & & $\mathrm{X}$ \\
\hline 1-SE-MW5-P & 14.73 & 2 & 3 & & $\mathrm{X}$ \\
\hline 1-NE-MWT8-P & 9.08 & 2 & NA & & $\mathrm{X}$ \\
\hline 1-NEC-MW9-P & 10.21 & 2 & 3 & & $\mathrm{X}$ \\
\hline 1-NEC-MW15-P & 12.78 & 4 & 5 & $\mathrm{X}$ & $\mathrm{X}$ \\
\hline 1-NE-MW17-P & 11.39 & 4 & 5 & & $\mathrm{X}$ \\
\hline 1-NE-MW23-P & 11.17 & 4 & 5 & $\mathrm{X}$ & $\mathrm{X}$ \\
\hline 1-NW-MW24-P & 11.93 & 4 & 5 & $\mathrm{X}$ & \\
\hline 1-NWC-MW28-P & 11.45 & 4 & 5 & & $\mathrm{X}$ \\
\hline 1-NEC-MW33-P & 10.04 & 4 & 5 & & $\mathrm{X}$ \\
\hline 1-NEC-MW34-P & 10.4 & 4 & 5 & $\mathrm{X}$ & $\mathrm{X}$ \\
\hline \multicolumn{6}{|l|}{ Shale (confining zone) } \\
\hline 1-NW-MW6-I & 17.97 & 2 & 3 & & $\mathrm{X}$ \\
\hline 1-SE-MW13-I & 21.56 & 2 & 5 & $\mathrm{X}$ & \\
\hline \multicolumn{6}{|l|}{ Bedrock aquifer (limestone) } \\
\hline 1-NEC-MW15-S & 40.64 & 4 & 10 & $\mathrm{X}$ & $\mathrm{X}$ \\
\hline 1-NEC-MW17-S & 38.68 & 4 & 10 & $\mathrm{X}$ & \\
\hline 1-NEC-MW34-S & 38.26 & 4 & 15 & & $\mathrm{X}$ \\
\hline 1-NE-MW23-S & 45.13 & 4 & 20 & $\mathrm{X}$ & $\mathrm{X}$ \\
\hline 1-NW-MW24-S & 37.77 & 4 & 15 & $\mathrm{X}$ & $\mathrm{X}$ \\
\hline
\end{tabular}


Tetra Tech NUS (2001) investigation were chosen for use in this investigation because they provided information on the potential for contaminant biodegradation. These included 11 wells in the overburden aquifer, 1 well in the shale, and 4 wells in the bedrock aquifer. In addition, Tetra Tech NUS (2001) collected ground-water samples for this investigation from 11 wells in the overburden aquifer during JanuaryFebruary 2000, which were analyzed for redox-sensitive compounds. During September 1999, the USGS collected a water sample from the target horizon in each sampled well using a peristaltic pump or a Bennett positive-displacement pump.

In general, the aquifers were low yielding. Very slow purging (less than $80 \mathrm{~mL} / \mathrm{min}$ ) using a peristaltic pump removed nearly all of the water in overburdenaquifer wells 1-NE-MW23-P, 1-NW-MW24-P, 1-NECMW15-P, and 1-NEC-MW34-P and in bedrock-aquifer well 1-NEC-MW17-S prior to collecting the samples. After pumping bedrock-aquifer well 1-NEC-MW15-S slowly (78 mL/min) for 1 hour and 42 minutes, virtually all pumped water continued to come from well storage, as determined by comparing the calculated change in water volume within the well to the measured volume of water pumped out of the well. The pumping rate in well 1-NEC-MW15-S was increased, lowering the water level in the well a total of $22 \mathrm{ft}$, whereupon the pump was turned off, and the well was allowed to remain undisturbed. After 1 hour and 17 minutes, however, the water level had not changed. Thus, well 1-NEC-MW15-S was determined to be poorly connected to the aquifer, and water samples collected from this well by the purge-and-sample method were regarded as questionable. Similarly, most of the water pumped from well 1-SE-MW13-I, after purging at a low rate (approximately $100 \mathrm{~mL} / \mathrm{min}$ ) for 30 minutes, appears to have come from well storage.

Well 1-NE-MW23-S was purged at a low rate (approximately $100 \mathrm{~mL} / \mathrm{min}$ ) for 30 minutes, and the pump was turned off. The well was allowed to recover for 2 hours prior to collecting a sample.

Tetra Tech NUS (20001) sampled the wells during January-February 2000. Well purging was accomplished by using either a 2-in-diameter submersible positive-displacement pump for the recharging bedrock wells or a disposable bailer for the lowvolume shallow wells or low-yielding deeper wells. Samples were collected after evacuating the well casing or after purging three casing volumes of water.
Water samples for analysis of VOCs were collected by filling pre-acidified $40-\mathrm{mL}$ glass volatile organic analysis vials. The vials were sealed with Teflon-lined bottle caps. Samples were sent to the laboratory for analysis using method $8260 \mathrm{~b}$ (U.S. Environmental Protection Agency (1999).

Ferrous iron [Fe(II)], hydrogen sulfide, dissolved oxygen (DO), $\mathrm{pH}$, water temperature, and $\mathrm{H}_{2}$ in ground water were measured in the field. The Fe(II) and hydrogen sulfide concentrations were measured using a Hach colorimetric method (Hach Company, 1992). DO was measured using the CHEMetrics ampoule method (American Society for Testing and Materials, 1994).

\section{Dissolved Hydrogen Sampling and Analysis}

$\mathrm{H}_{2}$, a transient intermediate product of anaerobic microbial metabolism, was used in this investigation as an indicator of TEAPs. Previous studies have concluded that characteristic $\mathrm{H}_{2}$ concentrations were 5-25 nM for methanogenesis, $1-4 \mathrm{nM}$ for sulfate reduction, and 0.1-0.8 nM for ferric iron [Fe(III)] reduction (Lovley and Goodwin,1988; Chapelle and Lovley, 1990; 1992; Chapelle and McMahon, 1991; Vroblesky and Chapelle, 1994).

$\mathrm{H}_{2}$ in ground water can be sampled by using a variety of methods. The approaches include the bubblestrip method (Chapelle and McMahon, 1991), a modification of the bubble-strip method (Microseeps, 2000), and the use of a downhole flow-through chamber with pneumatically activated valves (Chapelle and others, 1997). A gas-diffusion probe also has been used, but the probe produces anomalously high concentrations when deployed for periods of days (Kramer and Conrad, 1993). Diffusion samplers utilizing Teflon tubing also have been used to sample $\mathrm{H}_{2}$ (Chapelle and others, 1997). Recovery of $\mathrm{H}_{2}$ from the Teflon-tubing diffusion sampler involves opening one end of a long Teflon tube to ambient air while using a syringe to withdraw $\mathrm{H}_{2}$ from the other end.

In this investigation, a new type of $\mathrm{H}_{2}$ diffusion sampler was used to avoid direct exposure of the $\mathrm{H}_{2}$ to ambient air during sample recovery. The diffusion samplers used in this investigation were helium-filled vapor bags, each equipped with a syringe port. The samplers consisted of 2-in-diameter, 4-mil "lay-flat" low-density polyethylene (LDPE) tubing containing a semi-rigid LDPE mesh (commercially available as a dish scrubber). The LDPE tubing was heat sealed at both ends. The internal mesh prevented collapse of the 
bag due to vapor loss. The sealed tubing and mesh assembly was placed inside a rigid 2-in-diameter Teflon tube for structural support and then into a 3-indiameter LDPE tube that then was heat sealed at both ends. The Teflon tube and outer LDPE tube provided support to prevent hydrostatic pressure from collapsing the inner bag. The entire assembly was placed inside a 2.5-in-diameter LDPE mesh for protection against abrasion. To reduce introduction of oxygen into the samplers, each sampler was constructed at the site on the day of deployment in an anaerobic glove bag under a helium atmosphere. Samplers were stored in the glove bag until deployment in the wells.

As a preliminary test of the method's capability to collect vapor samples with $\mathrm{H}_{2}$ concentrations characteristic of predominant TEAP conditions, two $\mathrm{H}_{2}$ diffusion samplers were buried approximately $15 \mathrm{ft}$ apart in the organic-rich sediment of a freshwater swamp in Columbia, S.C. A cage containing crushed gypsum was attached to one of the diffusion samplers to provide a source of dissolved sulfate. The samplers were recovered after 22 days. The $\mathrm{H}_{2}$ concentration in the $\mathrm{H}_{2}$ diffusion sampler without the crushed gypsum was $5.3 \mathrm{nM}$, which is in the range of methanogenesis. The $\mathrm{H}_{2}$ concentration in the diffusion sampler with the attached gypsum was $3.4 \mathrm{nM}$, which is in the range of sulfate reduction. The organic-rich nature of the bed materials and the odorless bubbles that were released from the sediment indicate that the predominant TEAP in the sediment was methanogenesis, consistent with the interpretation based on the diffusion-sampler result. Given a source of dissolved sulfate, however, the predominant TEAP in a methanogenic environment can shift to sulfate reduction (Vroblesky and Chapelle, 1994). The probable TEAP in the direct vicinity of the crushed gypsum was sulfate reduction, consistent with the interpretation based on the diffusion-sampler result. Therefore, the $\mathrm{H}_{2}$ diffusion samplers appear to be capable of providing data to differentiate between sulfate reduction and methanogenesis.

As a rough estimate of diffusion-sampler equilibration time, a $\mathrm{H}_{2}$ diffusion sampler containing $13.95 \mathrm{nM}$ of $\mathrm{H}_{2}$ was allowed to equilibrate in an atmosphere containing $0.53 \mathrm{nM}$. The diffusion sampler was 88 percent equilibrated after 23 hours and 98 percent equilibrated after 34 hours.

During September 1999, the USGS, using the bubble-strip method (Chapelle and McMahon, 1991), also collected a dissolved $\mathrm{H}_{2}$ sample from wells where sufficient yield was available. Samples were collected using both the bubble-strip method and the diffusion samplers at two wells in the bedrock aquifer (1-NEMW23-S and 1-NW-MW24-S) and one well in the overburden aquifer (1-NEC-MW34-P). An $\mathrm{H}_{2}$ sample was collected from one additional well (1-NE-MW23-P) using only diffusion a sampler. $\mathrm{H}_{2}$ from all samplers was measured onsite using a gas chromatograph equipped with a reduction gas detector. At least two samples were collected and analyzed from each diffusion sampler. In addition, $\mathrm{H}_{2}$ samples were collected by Tetra Tech NUS (2001) during January-February 2000 from six wells in the overburden aquifer by using the Microseeps method; the samples were sent to a laboratory for analysis.

\section{Biodegradation Experiments}

The USGS conducted laboratory experiments of biodegradation activity on sediments from the station. The purposes of these experiments were to examine the chlorinated-solvent biodegradation potential in the northern part of the station and to elucidate probable biological mechanisms involved in the degradation.

\section{Sample Collection}

Samples for biodegradation experiments were collected by using two methodologies. Experiments concerning the potential for reductive dechlorination of trichloroethene (TCE) in the bedrock aquifer and the shale confining zone were conducted by collecting samples from downhole mesocosms. Experiments concerning biodegradation potential in the overburden aquifer were conducted using sediments collected in acetate sleeves by using push technology.

The downhole mesocosms consisted of crushed native rock (grain size $0.08-0.16 \mathrm{in}$.) obtained from drilling cores. Mesocosms deployed in the bedrock aquifer consisted of mixed limestone collected from stratigraphically correlative bedrock at the Okalona Park borehole in April 1999 (Charles Taylor, U.S. Geological Survey, written commun., 1999). The mesocosm deployed in the shale consisted of crushed shale from the same formation at a depth of 55-87 ft below land surface. The crushed rock was enclosed in a fiberglass or nylon mesh wrapped in aluminum foil and autoclaved.

Deployment of the mesocosms consisted of lowering the crushed-rock-filled bags into wells to target horizons and allowing them to remain undisturbed for approximately 3 months. A shale mesocosm 
was deployed in the screened interval of well 1-NWMW6-I. A bedrock aquifer mesocosm was deployed in well 1-NW-MW24-S. In addition, because the screened interval of well 1-SE-MW13-I transects both the lower part of the shale and the upper part of the bedrock aquifer, a shale mesocosm was deployed in well 1-SEMW13-I adjacent to the shale, and a limestone mesocosm was deployed in the same well adjacent to the bedrock aquifer. Upon recovery of the mesocosms, the crushed rock was transferred to glass containers and transported to the USGS laboratory in Columbia, S.C., where the samples were analyzed for biodegradation potential of TCE and acetate, as described below.

The sediment sample for biodegradation-potential experiments concerning the overburden aquifer was obtained by using push technology at well 1-NECMW34-P. The sample was collected from the saturated interval directly above the shale.

\section{Radiolabeled Compounds}

The potential for reductive dechlorination of TCE under anaerobic conditions and methylotrophic cometabolic oxidation of TCE under aerobic conditions was investigated using $\left[1,2-{ }^{14} \mathrm{C}\right] \mathrm{TCE}$ (neat; specific activity of $2.0 \mathrm{mCi} / \mathrm{mmole}$ ); Sigma Chemical Co., St. Louis, Mo.). In addition, an assessment of the in situ microbial activity in the shale and bedrock aquifers was made using $\left[2-{ }^{14} \mathrm{C}\right]$ acetate (aqueous solution; specific activity of $44.8 \mathrm{mCi} / \mathrm{mmole}$; Sigma Chemical Co., St. Louis, Mo.). Radiometric detection gas chromatography (GC/GRD) and liquid scintillation counting analyses demonstrated that greater than 98 percent of the total radioactivity present in the TCE and acetate stocks used in this study was, in fact, $\left[1,2-{ }^{14} \mathrm{C}\right] \mathrm{TCE}$ and $\left[2-{ }^{14} \mathrm{C}\right]$ acetate, respectively. The chemical purity (greater than 99 percent) of the $\left[1,2-{ }^{14} \mathrm{C}\right] \mathrm{TCE}$ and $\left[2-{ }^{14} \mathrm{C}\right]$ acetate was confirmed in our lab by flame ionization detection gas chromatography (GC/FID) and mass spectrometry gas chromatography (GC/MS) analyses. Methane amendments in the methylotrophic cometabolism study were made using high purity methane (chemical purity greater than 99 percent; Scott Specialty Gases, Plumsteadville, Pa.).

\section{Reductive Dechlorination Microcosm Experiments}

In brief, $10-\mathrm{mL}$ serum vials were amended with 5 grams of saturated, mesocosm material in an anaerobic glove-box ( 5 percent $\mathrm{H}_{2}, 95$ percent nitrogen atmosphere), sealed with Teflon-lined butyl rubber stoppers, and flushed with an excess $(1,000 \mathrm{~mL})$ of high purity helium. Experimental treatments were prepared in triplicate. Duplicate killed control microcosms were prepared as described and autoclaved twice for 1 hour at $15 \mathrm{psi}$ and $121{ }^{\circ} \mathrm{C}$. Duplicate sediment-free controls were prepared without mesocosm material and were autoclaved twice for 1 hour at 15 psi and $121^{\circ} \mathrm{C}$. Sediment microcosms were pre-incubated for 5 days to ensure anaerobic conditions and then amended with approximately $0.23 \mu \mathrm{Ci}(500,000 \mathrm{dpm})$ of $\left[1,2-{ }^{14} \mathrm{C}\right]$ TCE. Initial dissolved TCE concentrations in equilibrium with the headspace were approximately $4 \mathrm{mg} / \mathrm{L}$.

For the reductive dechlorination study, headspace concentrations of TCE and its chlorinated daughter products [dichloroethene (DCE) and vinyl chloride (VC)] and the radioactivity associated with TCE and its daughter products were monitored periodically over 90 days by removing $0.25 \mathrm{~mL}$ of headspace and analyzing by GC/FID coupled to GC/GRD. Headspace concentrations of methane, carbon dioxide, ethene, ethane, and radioactivity associated with each were monitored in the same manner using thermal conductivity detection gas chromatography (GC/TCD) coupled to $\mathrm{GC} /$ GRD. The headspace sample volumes were replaced with helium. The GC/GRD output was calibrated by liquid scintillation counting using carbon-14 radiolabeled bicarbonate $\left(\mathrm{H}^{14} \mathrm{CO}_{3}\right)$.

\section{Acetate Mineralization Microcosm Experiments}

The potential for microbial mineralization of acetate was investigated in microcosms containing shale material or limestone material from mesocosms that had been deployed in 1-SE-MW13-I for 3 months to determine whether the microcosms were microbially active. Microcosms were prepared as described above for the reductive dechlorination study, but were amended with approximately $0.23 \mu \mathrm{Ci}(500,000 \mathrm{dpm})$ of $\left[2-{ }^{14} \mathrm{C}\right]$ acetate rather than TCE. Initial dissolved acetate concentrations in equilibrium with the headspace were approximately $150 \mu \mathrm{g} / \mathrm{L}$. Headspace concentrations of carbon-14 radiolabeled methane $\left({ }^{14} \mathrm{CH}_{4}\right)$ and carbon dioxide $\left({ }^{14} \mathrm{CO}_{2}\right)$ were monitored as described above after a 48 -hour incubation period. The GC/GRD output was calibrated by liquid scintillation counting using $\mathrm{H}^{14} \mathrm{CO}_{3}$. 


\section{Methylotrophic Cometabolism Microcosm Experiments}

The co-occurrence of dissolved methane and DO in ground-water samples from overburden wells suggests that methylotrophic cometabolism may be a mechanism for microbial degradation of TCE at the station. To assess the potential for methylotrophic cometabolism in the overburden aquifer, a microcosm experiment was initiated using overburden material collected near well 1-NEC-MW34-P. In brief, 10-mL serum vials were amended with 5 grams of saturated, overburden material, sealed with Teflon-lined butyl rubber stoppers, and flushed with an excess $(1,000 \mathrm{~mL})$ of high purity air. Half of the prepared microcosms were then amended with methane to yield an initial headspace methane concentration of 1 percent (by volume). For each methane treatment, experimental microcosms were prepared in triplicate. Duplicate killed control microcosms were prepared as described previously and autoclaved twice for 1 hour at $15 \mathrm{psi}$ and $121^{\circ} \mathrm{C}$. Duplicate sediment-free controls were prepared without overburden material and were autoclaved twice for 1 hour at $15 \mathrm{psi}$ and $121^{\circ} \mathrm{C}$. The overburden microcosms were amended with approximately $0.23 \mu \mathrm{Ci}(500,000 \mathrm{dpm})$ of $\left[1,2-{ }^{14} \mathrm{C}\right] \mathrm{TCE}$. Initial dissolved TCE concentrations in equilibrium with the headspace were approximately $4 \mathrm{mg} / \mathrm{L}$.

Headspace concentrations of TCE and ${ }^{14} \mathrm{C}$ - TCE were monitored periodically over 90 days by removing $0.25 \mathrm{~mL}$ of headspace and analyzing by GC/FID coupled to GC/GRD. Headspace concentrations of methane and carbon dioxide and their associated radioactivity were monitored in the same manner using GC/TCD coupled to GC/GRD. The headspace sample volumes were replaced with high purity air. The GC/GRD output was calibrated by liquid scintillation counting using $\mathrm{H}^{14} \mathrm{CO}_{3}$. The results were corrected for losses due to headspace sample collection.

\section{RESULTS AND DISCUSSION}

Ground water at the station contains petroleum hydrocarbons and chlorinated solvents (table 2). The petroleum hydrocarbons are found only in the bedrock aquifer, and the chlorinated solvents are found only in the overburden aquifer. A possible exception to this is $7.5 \mathrm{mg} / \mathrm{L}$ of methylene chloride detected in one sample from the bedrock aquifer in well 1-NE-MW23-S (at a depth of $44 \mathrm{ft}$ in September 1999). Because methylene chloride is a common laboratory contaminant and it was not observed in other samples from the same well, its presence probably does not reflect actual groundwater concentrations. No VOCs were observed in water obtained from wells screened in the shale.

The chlorinated solvents present in the overburden aquifer include methylene chloride, tetrachloroethene (PCE), TCE, and the reduced daughter products of PCE and TCE dechlorination cis-1,2-DCE, trans1,2-DCE, and VC. Chlorinated solvents are present in the vicinity of building A (well 1-NW-MW24-P), building E (well 1-NEC-MW34-P) and along the northeastern boundary of the station (wells 1-NW-MW15P and 1-NW-MW23P). Tetra Tec NUS (2001) also reported VOC contamination at wells 1-SW-MW5-P (southwestern corner of the station) and at temporary wells south of buildings $\mathrm{F}$ and $\mathrm{G}$. Along the northeastern boundary of the station, water-level data show the predominant direction of ground-water flow to be toward the station from offsite areas (fig. 1), implying that contamination at wells 1-NW-MW15-P and 1-NW-MW23-P may be derived from offsite sources (Tetra Tech NUS, 2001). Elsewhere at the station, the chlorinated-solvent contamination probably is derived from station activities, although specific sources have not been identified.

Crude oil is present in the bedrock aquifer at the station as well as in surrounding areas (Charles J. Taylor, U.S. Geological Survey, written commun., 1996;

Environmental Liability Management, Inc., 1999), suggesting that the petroleum hydrocarbons are naturally derived. Low concentrations of methyl-tert-butyl ether in well 1-NW-MW24-S, however, suggest the possibility of an anthropogenic contribution (table 2).

\section{Predominant Terminal-Electron Accepting Processes}

The predominant TEAPs in anaerobic parts of the overburden aquifer appear to be sulfate reduction or iron reduction. A substantial amount of sulfate typically was present (39-980 mg/L), indicating that sufficient electron acceptors are available to support sulfate reduction (tables 3 and 4). The $\mathrm{H}_{2}$ concentrations in water from the overburden aquifer ranged from about 0.7 to about $2.27 \mathrm{nM}$ (table 3 ), and thus were characteristic of iron reduction $(0.2-0.8 \mathrm{nM})$ and sulfate reduction (1-4 $\mathrm{nM})$. 
Table 2. Volatile organic compound concentrations in ground water, September 1999 and January-February 2000, and historical sampling results,

Naval Surface Warfare Center, Louisville, Kentucky

[Sample depths for dates other than September 1999 are unknown. Data for dates other than September 1999, unless otherwise indicated, are from Tetra Tech NUS, Inc. (2001); ft bls, feet below land surface; $\mu \mathrm{g} / \mathrm{L}$, micrograms per liter; NS, no sample; <, less than; --, data not collected]

\begin{tabular}{|c|c|c|c|c|c|c|c|c|c|c|c|c|c|c|c|c|}
\hline \multirow[b]{2}{*}{ Well } & \multirow{2}{*}{$\begin{array}{c}\text { Sample } \\
\text { depth in } \\
\text { Sept.1999 } \\
\text { (ft bls) }\end{array}$} & \multicolumn{3}{|c|}{ Historical data } & \multicolumn{3}{|c|}{ This investigation } & \multicolumn{2}{|c|}{ Historical data } & \multicolumn{3}{|c|}{ This investigation } & \multicolumn{2}{|c|}{ Historical data } & \multicolumn{2}{|c|}{ This investigation } \\
\hline & & E. & $\begin{array}{l}\text { Sept.- } \\
\text { Dec., } \\
1996\end{array}$ & $\begin{array}{c}\text { April- } \\
\text { May } \\
1999\end{array}$ & $\begin{array}{l}\text { Sept. } \\
1999\end{array}$ & $\begin{array}{l}\text { Jan.- } \\
\text { Feb. } \\
2000\end{array}$ & $=$ & $\begin{array}{l}\text { Sept.- } \\
\text { Dec., } \\
1996\end{array}$ & $\begin{array}{l}\text { April- } \\
\text { May } \\
1999\end{array}$ & $\begin{array}{l}\text { Sept. } \\
1999\end{array}$ & $\begin{array}{l}\text { Jan.- } \\
\text { Feb. } \\
2000\end{array}$ & $=$ & $\begin{array}{l}\text { Sept.- } \\
\text { Dec., } \\
1996\end{array}$ & $\begin{array}{l}\text { April- } \\
\text { May } \\
1999\end{array}$ & $\begin{array}{l}\text { Sept. } \\
1999\end{array}$ & $\begin{array}{c}\text { Jan.- } \\
\text { Feb. } \\
2000\end{array}$ \\
\hline Overburden aquifer & & \pm & \multicolumn{4}{|c|}{ Tetrachloroethene ( $\mu \mathrm{g} / \mathrm{L})$} & $=$ & \multicolumn{4}{|c|}{ Methylene chloride ( $\mu \mathrm{g} / \mathrm{L})$} & 흘 & \multicolumn{4}{|c|}{ cis-1,2-Dichloroethene ( $\mu \mathrm{g} / \mathrm{L})$} \\
\hline 3-MW1-P & NS & $=$ & $<10$ & $<5$ & NS & $<1$ & E & $<10$ & $<5$ & NS & $<1$ & in & NS & $<5$ & NS & $<2$ \\
\hline 1-NW-MW4-P & NS & $=$ & $<10$ & $<5$ & NS & $<1$ & $=$ & $<10$ & $<5$ & NS & $<1$ & $=$ & NS & $<5$ & NS & $<2$ \\
\hline 1-SW-MW5-P & NS & = & $10 *$ & $6.8 *$ & NS & 12 & $=$ & $1^{*}$ & $<17$ & NS & $<1$ & $=$ & NS & $<17$ & NS & $<2$ \\
\hline 1-NE-MWT8-P & NS & e & $<50$ & $<10$ & NS & $<1$ & $=$ & $<50$ & $<10$ & NS & $<1$ & 를 & NS & 42 & NS & 400 \\
\hline 1-NEC-MW9-P & NS & $=$ & $<10$ & $<5$ & NS & $<1$ & = & $<10$ & $<5$ & NS & $<1$ & $=$ & NS & $<5$ & NS & 5 \\
\hline 1-NEC-MW15-P & 12 & 5 & $<330$ & $<5$ & $<5$ & $<1$ & ine & $<330$ & $2.5^{*}$ & $<5$ & $<1$ & $=$ & -- & 8.2 & 6.1 & 4 \\
\hline 1-NE-MW17-P & NS & $=$ & NS & $<5$ & NS & $<1$ & $=$ & NS & $<5$ & NS & $<1$ & $=$ & NS & $<5$ & NS & $<2$ \\
\hline 1-NE-MW23-P & 9 & E & NS & 16 & 57 & 19 & $=$ & NS & 18 & $<5$ & $<1$ & 를 & NS & 16 & 210 & 62 \\
\hline 1-NW-MW24-P & 11.5 & E & NS & 69 & 19 & NS & e & NS & 69 & $<5$ & NS & $=$ & NS & $<5$ & $<5$ & NS \\
\hline 1-NWC-MW28-P & NS & $=$ & NS & $<5$ & NS & $<1$ & a & NS & $<5$ & NS & $<1$ & e & NS & $<5$ & NS & $<2$ \\
\hline 1-NEC-MW33-P & NS & E & NS & $<5$ & NS & $.9 *$ & E & NS & $<5$ & NS & $<1$ & $=$ & NS & $<5$ & NS & $<2$ \\
\hline 1-NEC-MW34-P & \multirow[t]{2}{*}{8} & E & \multirow[t]{2}{*}{ NS } & \multirow[t]{2}{*}{$<5,000$} & \multirow[t]{2}{*}{$<5$} & \multirow[t]{2}{*}{$<1$} & \multirow{2}{*}{$=$} & \multirow[t]{2}{*}{ NS } & \multirow[t]{2}{*}{$<5,000$} & \multirow[t]{2}{*}{$<250$} & \multirow[t]{2}{*}{$<1$} & \multirow{2}{*}{\multicolumn{2}{|c|}{ NS }} & \multirow[t]{2}{*}{12,000} & \multirow[t]{2}{*}{6,500} & 28,000 \\
\hline Shale confining zone & & I & & & & & & & & & & & & & & \\
\hline 1-NW-MW6-I & NS & e. & $<10$ & $<5$ & NS & $<1$ & E & $<10$ & $<5$ & NS & $<1$ & $=$ & -- & $<5$ & NS & $<2$ \\
\hline 1-SE-MW13-I & 21 & $=$ & $<10$ & $<5$ & $<5$ & NS & 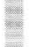 & $<10$ & $<5$ & $<5$ & NS & 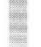 & $<10$ & $<5$ & $<5$ & NS \\
\hline Bedrock aquifer (limestone) & & e & & & & & $=$ & & & & & $=$ & & & & \\
\hline 1-NEC-MW15-S & 35 & eite & $<10$ & $<5$ & $<5$ & $<1$ & $=$ & $<10$ & $<5$ & $<5$ & $<1$ & $=$ & -- & $<5$ & $<5$ & $<2$ \\
\hline 1-NEC-MW17-S & 38 & 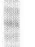 & $<10$ & $<5$ & $<5$ & NS & $=$ & $<10$ & $<5$ & $<5$ & NS & $=$ & -- & $<5$ & $<5$ & NS \\
\hline 1-NE-MW23-S & 25 & $=$ & NS & $<5$ & $<5$ & $<1$ & $=$ & NS & $<5$ & $<5$ & $<1$ & $=$ & FNS & $<5$ & $<5$ & $<2$ \\
\hline 1-NE-MW23-S & 44 & 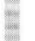 & NS & NS & $<5$ & NS & $=$ & NS & NS & 7.5 & NS & $=$ & NS & NS & $<5$ & NS \\
\hline 1-NW-MW24-S & 25 & ex & NS & $<5$ & $<5$ & $<1$ & $=$ & NS & $<100$ & NS & $<1$ & $=$ & NS & $<100$ & NS & $<2$ \\
\hline 1-NW-MW24-S & 30 & $=$ & NS & NS & $<5$ & NS & $=$ & NS & NS & $<5$ & NS & $=$ & NS & NS & $<5$ & NS \\
\hline 1-NEC-MW34-S & NS & E & NS & $<170$ & NS & $<1$ & $=$ & NS & $<170$ & NS & $<1$ & $=$ & NS & $<170$ & NS & $<2$ \\
\hline Overburden aquifer & & 플 & trans & 1,2-Dich & roethene & $\mathrm{g} / \mathrm{L})$ & $=$ & & ichloroe & hene $(\mu \mathrm{g} /$ & & = & & Vinyl chl & ride $(\mu \mathrm{g} / \mathrm{L}$ & \\
\hline 3-MW1-P & NS & $=$ & NS & $<5$ & NS & $<2$ & $=$ & $<10$ & $<5$ & NS & $<1$ & 른 & $<2$ & $<5$ & NS & $<2$ \\
\hline 1-NW-MW4-P & NS & $=$ & NS & $<5$ & NS & $<2$ & $=$ & $<10$ & $<5$ & NS & $<1$ & e & $<2$ & $<5$ & NS & $<1$ \\
\hline 1-SW-MW5-P & NS & e. & NS & $<17$ & NS & $<2$ & $=$ & $2 *$ & $<17$ & NS & 2 & = & $<2$ & $<17$ & NS & $<2$ \\
\hline 1-NE-MWT8-P & NS & $=$ & NS & $1.3 *$ & NS & 12 & $=$ & 70 & 11 & NS & 110 & $=$ & 67 & $4.9 *$ & NS & 130 \\
\hline 1-NEC-MW9-P & NS & 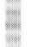 & NS & $<5$ & NS & $<2$ & e & $<10$ & $<5$ & NS & $<1$ & $=$ & $<2$ & $<5$ & NS & $<2$ \\
\hline 1-NEC-MW15-P & 12 & $=$ & -- & $<5$ & $<5$ & $<2$ & $=$ & 2,000 & 34 & 50 & 11 & E & $54 *$ & 6.6 & $<2$ & $2^{*}$ \\
\hline 1-NE-MW17-P & NS & 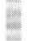 & NS & $<5$ & NS & $<2$ & $=$ & NS & $<5$ & NS & $<1$ & 둥 & NS & $<5$ & NS & $<2$ \\
\hline
\end{tabular}


Table 2. Volatile organic compound concentrations in ground water, September 1999 and January-February 2000, and historical sampling results, Naval Surface Warfare Center, Louisville, Kentucky (Continued)

[Sample depths for dates other than September 1999 are unknown. Data for dates other than September 1999, unless otherwise indicated, are from Tetra Tech NUS, Inc. (2001); ft bls, feet below land surface; $\mu \mathrm{g} / \mathrm{L}$, micrograms per liter; NS, no sample; <, less than; --, data not collected]

\begin{tabular}{|c|c|c|c|c|c|c|c|c|c|c|c|c|c|}
\hline \multirow[b]{2}{*}{ Well } & \multirow{2}{*}{$\begin{array}{c}\text { Sample } \\
\text { depth in } \\
\text { Sept. } 1999 \\
\text { (ft bls) }\end{array}$} & \multicolumn{2}{|c|}{ Historical data } & \multicolumn{2}{|c|}{ This investigation } & \multicolumn{2}{|c|}{ Historical data } & \multicolumn{2}{|c|}{ This investigation } & \multicolumn{2}{|c|}{ Historical data } & \multicolumn{2}{|c|}{ This investigation } \\
\hline & & $\begin{array}{c}\text { Sept.- } \\
\text { Dec., } \\
1996\end{array}$ & $\begin{array}{c}\text { April- } \\
\text { May } \\
1999\end{array}$ & $\begin{array}{l}\text { Sept. } \\
1999\end{array}$ & $\begin{array}{l}\text { Jan.- } \\
\text { Feb. } \\
2000\end{array}$ & $\begin{array}{c}\text { Sept.- } \\
\text { Dec., } \\
1996\end{array}$ & $\begin{array}{c}\text { April- } \\
\text { May } \\
1999\end{array}$ & $\begin{array}{l}\text { Sept. } \\
1999\end{array}$ & $\begin{array}{l}\text { Jan.- } \\
\text { Feb. } \\
2000\end{array}$ & $\begin{array}{c}\text { Sept.- } \\
\text { Dec., } \\
1996\end{array}$ & $\begin{array}{c}\text { April- } \\
\text { May } \\
1999\end{array}$ & $\begin{array}{l}\text { Sept. } \\
1999\end{array}$ & $\begin{array}{l}\text { Jan.- } \\
\text { Feb. } \\
2000\end{array}$ \\
\hline Overburden aquifer (Cont.) & & \multicolumn{4}{|c|}{ trans-1,2-Dichloroethene ( $\mu \mathrm{g} / \mathrm{L})$ (Cont.) } & \multicolumn{4}{|c|}{ Trichloroethene ( $\mu \mathrm{g} / \mathrm{L})$ (Cont.) } & \multicolumn{4}{|c|}{ Vinyl chloride ( $\mu \mathrm{g} / \mathrm{L})$ (Cont.) } \\
\hline 1-NE-MW23-P & 9 & NS & $<5$ & 10 & 2 & NS & 5.9 & 110 & 16 & NS & $1.3^{*}$ & 26 & 7 \\
\hline 1-NW-MW24-P & 11.5 & NS & $<5$ & $<5$ & NS & NS & 17 & 8.3 & NS & NS & $<5$ & $<2$ & NS \\
\hline 1-NWC-MW28-P & NS & NS & $<5$ & NS & $<2$ & NS & $<5$ & NS & $<1$ & NS & $<5$ & NS & $<2$ \\
\hline 1-NEC-MW33-P & NS & NS & $<5$ & NS & $<2$ & NS & $<5$ & NS & $<1$ & NS & $<5$ & NS & $<2$ \\
\hline 1-NEC-MW34-P & 8 & NS & $<5,000$ & 100 & 130 & NS & $<5,000$ & 76 & 310 & NS & $<5,000$ & 510 & 890 \\
\hline \multicolumn{14}{|l|}{ Shale confining zone } \\
\hline 1-NW-MW6-I & NS & -- & $<5$ & NS & $<2$ & $<10$ & $<5$ & NS & $<1$ & $<2$ & $<5$ & NS & $<2$ \\
\hline 1-SE-MW13-I & 21 & -- & $<5$ & $<5$ & NS & $<10$ & $<5$ & $<5$ & NS & $<2$ & $<5$ & $<2$ & NS \\
\hline \multicolumn{14}{|l|}{ Bedrock aquifer (limestone) } \\
\hline 1-NEC-MW15-S & 35 & -- & $<5$ & $<5$ & $<2$ & $<10$ & $<5$ & $<5$ & $<1$ & $<2$ & $<5$ & $<2$ & $<2$ \\
\hline 1-NEC-MW17-S & 38 & -- & $<5$ & $<5$ & NS & $<10$ & $<5$ & $<5$ & NS & $<2$ & $<5$ & $<2$ & NS \\
\hline 1-NE-MW23-S & 25 & NS & $<5$ & $<5$ & $<2$ & NS & $<5$ & $<5$ & $<1$ & NS & $<5$ & $<2$ & $<2$ \\
\hline 1-NE-MW23-S & 44 & NS & NS & $<5$ & NS & NS & NS & $<5$ & NS & NS & NS & $<2$ & NS \\
\hline 1-NW-MW24-S & 25 & NS & $<100$ & NS & $<2$ & NS & $<100$ & NS & $<1$ & NS & $<100$ & NS & $<2$ \\
\hline 1-NW-MW24-S & 30 & NS & NS & $<5$ & NS & NS & NS & $<5$ & NS & NS & NS & $<2$ & NS \\
\hline 1-NEC-MW34-S & NS & NS & $<170$ & NS & $<2$ & NS & $<170$ & NS & $<1$ & NS & $<170$ & NS & $<2$ \\
\hline Overburden aquifer & & \multicolumn{4}{|c|}{ Chloroethane $(\mu \mathbf{g} / \mathbf{L})$} & \multicolumn{4}{|c|}{ Benzene ( $\mu \mathbf{g} / \mathbf{L})$} & \multicolumn{4}{|c|}{ Total xylenes ( $\mu \mathrm{g} / \mathrm{L})$} \\
\hline 3-MW1-P & NS & $<10$ & $<5$ & NS & $<2$ & $<10$ & $<5$ & NS & $<1$ & $<10$ & $<5$ & NS & $<1$ \\
\hline 1-NW-MW4-P & NS & $<10$ & $<5$ & NS & $<2$ & $<10$ & $<5$ & NS & $<1$ & $<10$ & $<5$ & NS & $<1$ \\
\hline 1-SW-MW5-P & NS & $<10$ & $<17$ & NS & $<2$ & $<10$ & $<17$ & NS & $<1$ & $<10$ & $<17$ & NS & $<1$ \\
\hline 1-NE-MWT8-P & NS & $<50$ & $<10$ & NS & $<2$ & $<50$ & $<10$ & NS & $6 *$ & $<50$ & $<10$ & NS & $<1$ \\
\hline 1-NEC-MW9-P & NS & $<10$ & $<5$ & NS & $<2$ & $<10$ & $<5$ & NS & $<1$ & $<10$ & $<5$ & NS & $<1$ \\
\hline 1-NEC-MW15-P & 12 & $<330$ & $<5$ & $<5$ & $<2$ & $<330$ & $<5$ & $<5$ & $<1$ & $<330$ & $<5$ & $<5$ & $<1$ \\
\hline 1-NE-MW17-P & NS & NS & $<5$ & NS & $<2$ & NS & $<5$ & NS & $<1$ & NS & $<5$ & NS & $<1$ \\
\hline 1-NE-MW23-P & 9 & NS & $<5$ & $<5$ & $<2$ & NS & $<5$ & $<5$ & $<1$ & NS & $<5$ & $<5$ & $<1$ \\
\hline 1-NW-MW24-P & 11.5 & NS & $<5$ & $<5$ & NS & NS & $<5$ & $<5$ & NS & NS & $<5$ & $<5$ & NS \\
\hline 1-NWC-MW28-P & NS & NS & $<5$ & NS & $<2$ & NS & $<5$ & NS & $<1$ & NS & $<5$ & NS & $<1$ \\
\hline 1-NEC-MW33-P & NS & NS & $<5$ & NS & $<2$ & NS & $<5$ & NS & $<1$ & NS & $5.8^{*}$ & NS & $<1$ \\
\hline 1-NEC-MW34-P & 8 & NS & $<5,000$ & $<250$ & $<2$ & NS & $<5,000$ & $<5$ & $<1$ & NS & $<5,000$ & $<5$ & $<1$ \\
\hline \multicolumn{14}{|l|}{ Shale confining zone } \\
\hline 1-NW-MW6-I & NS & $<10$ & $<5$ & NS & $<2$ & $<10$ & $<5$ & NS & $<1$ & $<10$ & $<5$ & NS & $<1$ \\
\hline 1-SE-MW13-I & 21 & $<10$ & $<5$ & $<5$ & NS & $<10$ & $<5$ & $<5$ & NS & $<10$ & $<5$ & $<5$ & NS \\
\hline
\end{tabular}


Table 2. Volatile organic compound concentrations in ground water, September 1999 and January-February 2000, and historical sampling results, Naval Surface Warfare Center, Louisville, Kentucky (Continued)

[Sample depths for dates other than September 1999 are unknown. Data for dates other than September 1999, unless otherwise indicated, are from Tetra Tech NUS, Inc. (2001); ft bls, feet below land surface; $\mu \mathrm{g} / \mathrm{L}$, micrograms per liter; NS, no sample; <, less than; --, data not collected]

\begin{tabular}{|c|c|c|c|c|c|c|c|c|c|c|c|c|c|c|c|c|}
\hline \multirow[b]{2}{*}{ Well } & \multirow{2}{*}{$\begin{array}{c}\text { Sample } \\
\text { depth in } \\
\text { Sept.1999 } \\
\text { (ft bls) }\end{array}$} & \multicolumn{3}{|c|}{ Historical data } & \multicolumn{2}{|c|}{ This investigation } & & \multicolumn{2}{|c|}{ Historical data } & \multicolumn{3}{|c|}{ This investigation } & \multicolumn{2}{|c|}{ Historical data } & \multicolumn{2}{|c|}{ This investigation } \\
\hline & & 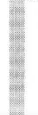 & $\begin{array}{c}\text { Sept.- } \\
\text { Dec., } \\
1996\end{array}$ & $\begin{array}{l}\text { April- } \\
\text { May } \\
1999\end{array}$ & $\begin{array}{l}\text { Sept. } \\
1999\end{array}$ & $\begin{array}{l}\text { Jan.- } \\
\text { Feb. } \\
2000\end{array}$ & $=$ & $\begin{array}{c}\text { Sept.- } \\
\text { Dec., } \\
1996\end{array}$ & $\begin{array}{c}\text { April- } \\
\text { May } \\
1999\end{array}$ & $\begin{array}{l}\text { Sept. } \\
1999\end{array}$ & $\begin{array}{l}\text { Jan.- } \\
\text { Feb. } \\
2000\end{array}$ & e & $\begin{array}{l}\text { Sept.- } \\
\text { Dec., } \\
1996\end{array}$ & $\begin{array}{c}\text { April- } \\
\text { May } \\
1999\end{array}$ & $\begin{array}{l}\text { Sept. } \\
1999\end{array}$ & $\begin{array}{l}\text { Jan.- } \\
\text { Feb. } \\
2000\end{array}$ \\
\hline Bedrock aquifer (limestone) & & exis & \multicolumn{4}{|c|}{ Chloroethane ( $\mu \mathrm{g} / \mathrm{L})$ (Cont.) } & $=$ & \multicolumn{4}{|c|}{ Benzene ( $\mu \mathrm{g} / \mathrm{L})$ (Cont.) } & $=$ & \multicolumn{4}{|c|}{ Total xylenes ( $\mu \mathrm{g} / \mathrm{L}$ ) (Cont.) } \\
\hline 1-NEC-MW15-S & 35 & e- & $<10$ & $<5$ & $<5$ & $<2$ & $=$ & $5^{*}$ & 1.9 & $<5$ & 3 & $=$ & 23 & 14 & 25 & 44 \\
\hline 1-NEC-MW17-S & 38 & $=$ & $<10$ & $<5$ & $<5$ & NS & $=$ & $2 *$ & 36 & 36 & NS & E & $1^{*}$ & 37 & $<5$ & NS \\
\hline 1-NE-MW23-S & 25 & $=$ & NS & $<5$ & $<5$ & $<2$ & = & NS & $<5$ & $<5$ & $<1$ & = & NS & $<5$ & $<5$ & $<1$ \\
\hline 1-NE-MW23-S & 44 & $=$ & NS & NS & $<5$ & NS & e & NS & NS & 51 & NS & $=$ & NS & NS & 34 & NS \\
\hline 1-NW-MW24-S & 25 & 5 & NS & 1 & NS & $<2$ & $=$ & NS & $<100$ & $<5$ & 3 & 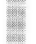 & NS & 5,200 & 350 & 680 \\
\hline 1-NW-MW24-S & 30 & $=$ & NS & NS & $<5$ & NS & $=$ & NS & NS & 14 & NS & $=$ & NS & NS & 1,100 & NS \\
\hline 1-NEC-MW34-S & NS & E & NS & $<170$ & NS & $<2$ & ente & NS & 190 & NS & 81 & $=$ & NS & 320 & NS & 140 \\
\hline Overburden aquifer & & in & \multicolumn{4}{|c|}{ Methyl-tert-butyl ether $(\mu \mathrm{g} / \mathrm{L})$} & in & \multicolumn{4}{|c|}{ Toluene $(\mu \mathrm{g} / \mathrm{L})$} & mate & \multicolumn{4}{|c|}{ Ethyl benzene ( $\mu \mathrm{g} / \mathrm{L})$} \\
\hline 3-MW1-P & NS & is & NS & $<10$ & NS & $<10$ & $=$ & $<10$ & $<5$ & NS & $<1$ & 는 & $<10$ & $<5$ & NS & $<1$ \\
\hline 1-NW-MW4-P & NS & tenta & NS & NS & NS & $<10$ & $=$ & $<10$ & $<5$ & NS & $<1$ & (3) & $<10$ & $<5$ & NS & $<1$ \\
\hline 1-SW-MW5-P & NS & $=$ & NS & NS & NS & $<10$ & =i & $<10$ & $<17$ & NS & $<1$ & $=$ & $<10$ & $<17$ & NS & $<1$ \\
\hline 1-NE-MWT8-P & NS & $=$ & NS & NS & NS & $<10$ & $=$ & $<50$ & $<10$ & NS & $<1$ & $=$ & $<50$ & $<10$ & NS & $<1$ \\
\hline 1-NEC-MW9-P & NS & $=$ & NS & $<5$ & NS & $<10$ & $=$ & $<10$ & $<5$ & NS & $<1$ & $=$ & $<10$ & $<5$ & NS & $<1$ \\
\hline 1-NEC-MW15-P & 12 & 달 & NS & NS & $<5$ & $<10$ & 늘 & $<330$ & NS & $<5$ & NS & $=$ & $<330$ & $<5$ & $<5$ & NS \\
\hline 1-NE-MW17-P & NS & in & NS & NS & NS & $<10$ & e & NS & $<5$ & NS & $<1$ & $=$ & NS & $<5$ & NS & $<1$ \\
\hline 1-NE-MW23-P & 9 & 를 & NS & NS & $<5$ & $<10$ & 늘 & NS & $<5$ & $<5$ & $<1$ & $=$ & NS & $<5$ & $<5$ & $<1$ \\
\hline 1-NW-MW24-P & 11.5 & in & NS & NS & $<5$ & NS & 랄 & NS & $<5$ & $<5$ & NS & $=$ & NS & $<5$ & $<5$ & NS \\
\hline 1-NWC-MW28-P & NS & y & NS & NS & NS & $<10$ & $=$ & NS & $<5$ & NS & $<1$ & $=$ & NS & $<5$ & NS & $<1$ \\
\hline 1-NEC-MW33-P & NS & 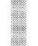 & NS & NS & NS & $<10$ & $=$ & NS & $<5$ & NS & $<1$ & $=$ & NS & $0.73^{*}$ & NS & $<1$ \\
\hline 1-NEC-MW34-P & 8 & 를 & NS & NS & $<5$ & $<10$ & $=$ & NS & $<5,000$ & $<5$ & $<1$ & $=$ & NS & $<5,000$ & $<5$ & $<1$ \\
\hline Shale confining zone & & & & & & & & & & & & & & & & \\
\hline 1-NW-MW6-I & NS & 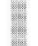 & NS & NS & NS & $<10$ & 10 & $<10$ & $<5$ & NS & $<1$ & $=$ & $<10$ & $<5$ & NS & $<1$ \\
\hline 1-SE-MW13-I & 21 & 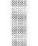 & NS & NS & $<5$ & NS & Jis & $<10$ & $<5$ & $<5$ & NS & in & $<10$ & $<5$ & $<5$ & NS \\
\hline Bedrock aquifer (limestone) & & & & & & & & & & & & & & & & \\
\hline 1-NEC-MW15-S & 35 & $=$ & NS & NS & $<5$ & $<10$ & & 17 & 6.1 & 11 & 16 & 照 & $6^{*}$ & 3.3 & 7.5 & 12 \\
\hline 1-NEC-MW17-S & 38 & 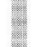 & NS & NS & $<5$ & NS & E & $3 *$ & 30 & 13 & NS & $=$ & $<10$ & 11 & $<5$ & NS \\
\hline 1-NE-MW23-S & 25 & & NS & NS & $<5$ & $<10$ & & NS & $<5$ & $<5$ & $<1$ & 到 & NS & $<5$ & $<5$ & $<1$ \\
\hline 1-NE-MW23-S & 44 & $=$ & NS & NS & $<5$ & NS & E & NS & NS & $<5$ & NS & 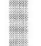 & NS & NS & 16 & NS \\
\hline 1-NW-MW24-S & 25 & 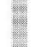 & NS & NS & 29 & $5^{*}$ & 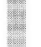 & NS & 2,100 & 18 & 24 & $=$ & NS & $<100$ & 96 & 150 \\
\hline 1-NW-MW24-S & 30 & 籍 & NS & NS & 31 & NS & $=$ & NS & NS & 59 & NS & 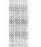 & NS & NS & 220 & NS \\
\hline 1-NEC-MW34-S & NS & E & NS & NS & NS & $<10$ & $=$ & NS & 280 & NS & 28 & 留 & NS & $90 *$ & NS & 68 \\
\hline
\end{tabular}


Table 2. Volatile organic compound concentrations in ground water, September 1999 and January-February 2000, and historical sampling results, Naval Surface Warfare Center, Louisville, Kentucky (Continued)

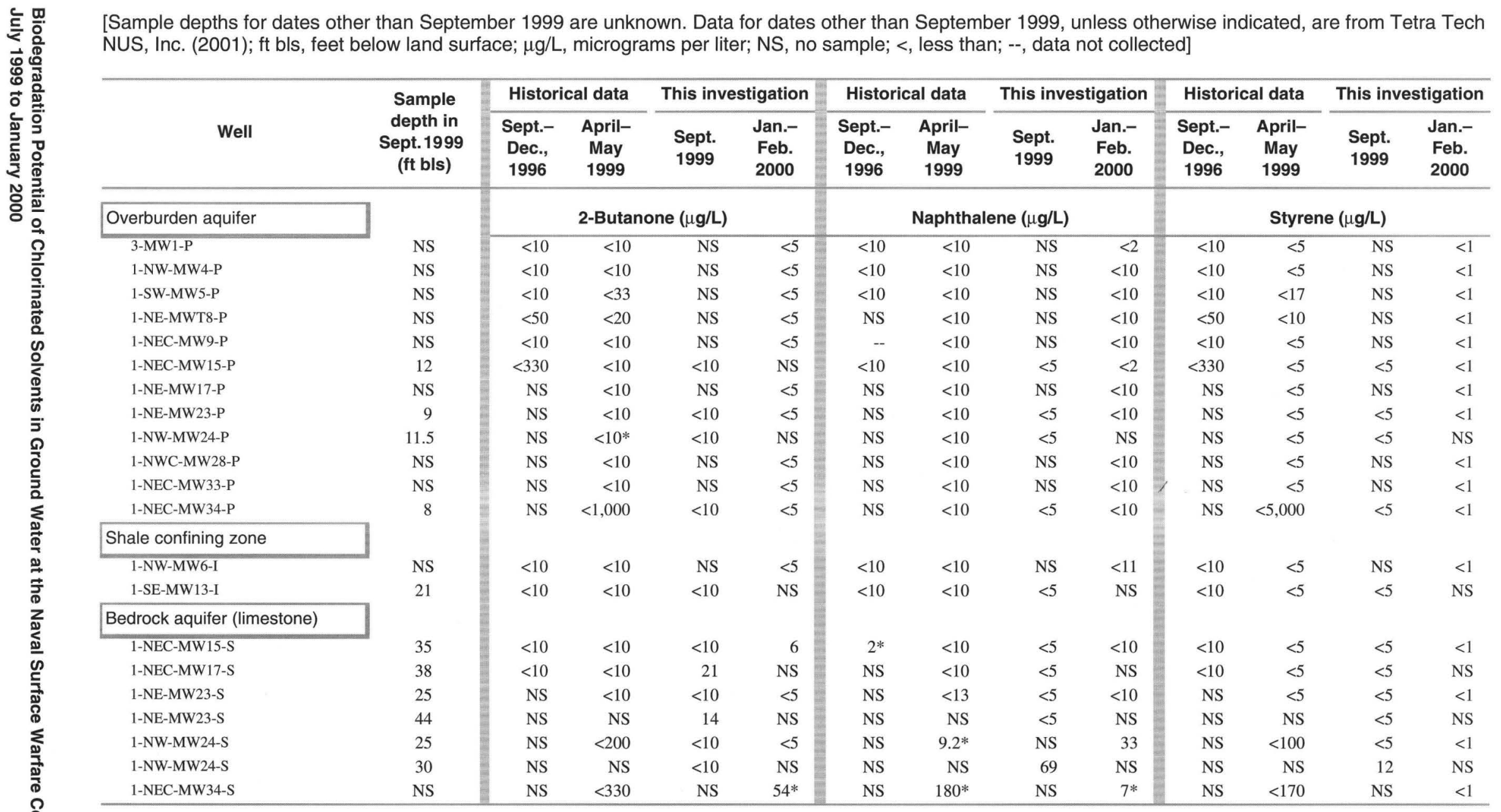

*Estimated value for a concentration detected below the method detection limit. 
Table 3. Inorganic properties, organic acids, and dissolved gases in ground water from the overburden and bedrock aquifers and the shale confining zone, September 1999, Naval Surface Warfare Center, Louisville, Kentucky

[ft btoc, feet below top of casing; mg/L, milligrams per liter; $\mu \mathrm{M}$, micromoles; $\mathrm{nM}$, nanomoles; Hdiff, dissolved hyrogen diffusion sampler; BS, bubble-strip method; -- data not collected. Nitrate, phosphate, propionate, n-butyrate, i- and n-valerate were not detected in any of the samples]

\begin{tabular}{|c|c|c|c|c|c|c|c|c|c|c|c|c|}
\hline \multirow[t]{2}{*}{ Sample } & \multirow[t]{2}{*}{$\begin{array}{l}\text { Sample } \\
\text { depth } \\
\text { (ft btoc) }\end{array}$} & \multirow[t]{2}{*}{$\begin{array}{c}\text { Chloride } \\
\text { (mg/L) }\end{array}$} & \multirow[t]{2}{*}{$\begin{array}{l}\text { Sulfate } \\
\text { (mg/L) }\end{array}$} & \multirow[t]{2}{*}{$\begin{array}{l}\text { Iron (II) } \\
\text { (mg/L) }\end{array}$} & \multirow[t]{2}{*}{$\begin{array}{c}\text { Formate } \\
(\mu \mathrm{M})\end{array}$} & \multirow[t]{2}{*}{$\begin{array}{c}\text { Acetate } \\
(\mu \mathrm{M})\end{array}$} & \multirow{2}{*}{$\begin{array}{c}\text { Dissolved } \\
\text { inorganic } \\
\text { carbon } \\
\text { (mg/L) }\end{array}$} & \multirow[t]{2}{*}{$\begin{array}{l}\text { Methane } \\
\text { (mg/L) }\end{array}$} & \multirow{2}{*}{$\begin{array}{c}\text { Dissolved } \\
\text { oxygen } \\
\text { (mg/L) }\end{array}$} & \multirow[t]{2}{*}{$\begin{array}{l}\text { Sulfide } \\
\text { (mg/L) }\end{array}$} & \multicolumn{2}{|c|}{$\begin{array}{l}\text { Dissolved } \\
\text { hydrogen } \\
(\mathrm{nM})\end{array}$} \\
\hline & & & & & & & & & & & Hdiff & BS \\
\hline \multicolumn{13}{|l|}{ Overburden aquifer } \\
\hline 1-NEC-MW15-P & 12 & 57.6 & 169.1 & 1 & $<5$ & $<5$ & 641.2 & -- & 0.25 & ND & -- & -- \\
\hline 1-NE-MW23-P & 9 & 22.0 & 344.0 & 1.5 & $<5$ & $<5$ & $1,739.5$ & -- & $0.7^{*} ; 2.5^{* *}$ & $<0.2$ & 1.6 & -- \\
\hline 1-NW-MW24-P & 11.5 & 62.6 & 66.5 & -- & $<5$ & $<5$ & 285.3 & -- & -- & -- & -- & -- \\
\hline 1-NEC-MW34-P & 8 & 95.3 & 342.6 & 3.5 & $<5$ & $<5$ & $1,140.2$ & 3.9 & 0.45 & 0.25 & 0.7 & 0.7 \\
\hline \multicolumn{13}{|c|}{ Shale confining zone } \\
\hline 1-SW-MW13-I & 21 & -- & -- & -- & -- & -- & -- & 159.4 & -- & -- & -- & -- \\
\hline \multicolumn{13}{|c|}{ Bedrock aquifer (limestone) } \\
\hline 1-NEC-MW17-S & 38 & $7,322.0$ & 267.7 & 8 & $<5$ & 14.0 & $1,938.8$ & 41.2 & 0.25 & 0.6 & -- & -- \\
\hline 1-NE-MW23-S & 24 & $4,648.3$ & 26.3 & 1.5 & $<5$ & $<5$ & -- & 80.6 & 0.25 & -- & -- & -- \\
\hline 1-NE-MW23-S & 45 & $5,232.0$ & 24.7 & -- & $<5$ & 27.6 & $1,757.7$ & 87.0 & 0.01 & 0.5 & 1.9 & 1 \\
\hline 1-NW-MW24-S & 25 & $1,424.7$ & 16.6 & 1.5 & $<5$ & 7.1 & $1,818.3$ & 89.8 & 0.4 & -- & -- & -- \\
\hline
\end{tabular}

*After purging 2 gallons.

**After purging 4 gallons.

Table 4. Inorganic properties and dissolved gases in ground water from the overburden aquifer, January-February 2000 , Naval Surface Warfare Center, Louisville, Kentucky

[Data from Kenneth Cottrell, Tetra Tech NUS, written commun., 2000; mg/L, milligrams per liter; $\mu \mathrm{g} / \mathrm{L} ;$ micrograms per liter; ng/L, nanograms per liter; nM, nanomoles per liter; TOC, total organic carbon; NS, not sampled]

\begin{tabular}{|c|c|c|c|c|c|c|c|c|c|c|c|c|c|c|}
\hline Well ID & $\begin{array}{l}\text { Bicarbonate } \\
\text { alkalinity } \\
\text { (mg/L) }\end{array}$ & $\begin{array}{c}\text { Chloride } \\
\text { (mg/L) }\end{array}$ & $\begin{array}{l}\text { Sulfate } \\
\text { (mg/L) }\end{array}$ & $\begin{array}{l}\text { Iron(II) } \\
\text { (mg/L) }\end{array}$ & $\begin{array}{l}\text { Manganese } \\
(\mathrm{mg} / \mathrm{L})\end{array}$ & $\begin{array}{l}\text { Nitrite } \\
\text { (mg/L) }\end{array}$ & $\begin{array}{l}\text { Nitrate } \\
\text { (mg/L) }\end{array}$ & $\begin{array}{l}\text { Phosphate } \\
\text { (mg/L) }\end{array}$ & $\begin{array}{c}\text { TOC } \\
\text { (mg/L) }\end{array}$ & $\begin{array}{l}\text { Dissolved } \\
\text { oxygen } \\
\text { (mg/L) }\end{array}$ & $\begin{array}{c}\text { Methane } \\
(\mu \mathrm{g} / \mathrm{L})\end{array}$ & $\begin{array}{c}\text { Ethane } \\
\text { (ng/L) }\end{array}$ & $\begin{array}{c}\text { Ethene } \\
\text { (ng/L) }\end{array}$ & $\begin{array}{c}\text { Dissolved } \\
\text { hydrogen } \\
(\mathrm{nM})^{*}\end{array}$ \\
\hline 1-NEC-MW15-P & 26 & 64.0 & 160 & 1.4 & 2.3 & $<0.05$ & 0.110 & $<0.05$ & 4.6 & NS & 29.32 & 125 & 4804 & 1.69 \\
\hline 1-NEC-MW33-P & 60 & 190.0 & 100 & 0.1 & 0.5 & $<5$ & $0.05 \mathrm{U}$ & $<0.05$ & 3.1 & 2.00 & 0.06 & $<5$ & $<5$ & NS \\
\hline 1-NEC-MW34-P & 190 & 120.0 & 180 & 0.7 & 2.3 & $<0.05$ & 0.220 & $<0.05$ & 4.6 & 1.50 & 858.80 & 4,752 & 38,794 & 1.75 \\
\hline 1-NE-MW17-P & 360 & 55.0 & 100 & NS & NS & $<0.05$ & 0.083 & $<0.05$ & 18.0 & 0.80 & 10.75 & 65 & 16 & 0.71 \\
\hline 1-NE-MW23-P & 240 & 10.0 & 980 & NS & NS & $<0.05$ & 0.830 & $<0.05$ & 7.0 & NS & 11.56 & 157 & 378 & 2.09 \\
\hline 1-NE-MWT8-P & 120 & 680.0 & 180 & NS & NS & $<0.05$ & 0.05 & $<0.05$ & 12.0 & 0.35 & 277.50 & 2,394 & 1,111 & 0.79 \\
\hline 1-NWC-MW28-P & 160 & 6.9 & 39 & 7.8 & 10.3 & $<0.05$ & 0.200 & $<0.05$ & 8.3 & NS & $1,15.20$ & 19 & 53 & 2.27 \\
\hline 1-NW-MW24-P & 58 & 40.0 & 54 & 0.018 & 0.0 & $<0.5$ & 1.700 & $<0.05$ & 2.0 & 4.50 & 0.11 & 8 & 19 & NS \\
\hline 1-NW-MW4-P & 83 & 49.0 & 210 & 1.3 & 11.2 & $<0.05$ & 0.093 & $<0.05$ & 8.7 & NS & 20.45 & 19 & 27 & NS \\
\hline 1-SW-MW5-P & 120 & 20.0 & 160 & 1.0 & 7.3 & $<0.5$ & 0.130 & $<0.05$ & 8.2 & NS & 31.42 & 40 & 28 & NS \\
\hline 3-MW1-P & 540 & 64.0 & 210 & 2.4 & 0.2 & $<0.05$ & $<0.05$ & $<0.05$ & 2.7 & 0.80 & 152.70 & 194 & 18 & NS \\
\hline
\end{tabular}

*Analyzed by Microseeps method. 
In general, the $\mathrm{H}_{2}$ results from each of the three $\mathrm{H}_{2}$-collection methods provided consistent TEAP interpretations. A possible exception is at well 1-NECMW34-P, where both the diffusion sampler and the bubble-strip method provided $\mathrm{H}_{2}$ concentrations characteristic of iron reduction ( $0.7 \mathrm{nM})$ in September 1999 (table 3), and the Microseeps method in the same well during the January-February 2000 sampling showed a $\mathrm{H}_{2}$ value characteristic of sulfate reduction $(1.75 \mathrm{nM})$ (table 4). The agreement between the bubble-strip method and the diffusion sampler method implies that both were accurate. Thus, the predominant TEAP probably shifted from Fe(III) reduction in September 1999 to sulfate reduction at the time of the January-February 2000 sampling event. Such shifts are not unusual in contaminated ground-water systems (Vroblesky and Chapelle, 1994). Supporting evidence for the shift is the observation that more dissolved $\mathrm{Fe}$ (II) $(3.5 \mathrm{mg} / \mathrm{L})$ and sulfate $(342.6 \mathrm{mg} / \mathrm{L})$ were present in ground water at well 1-NEC-MW34-P when the $\mathrm{H}_{2}$ concentrations were characteristic of $\mathrm{Fe}(\mathrm{III})$ reduction, than during the January-February 2000 sampling event $[0.7 \mathrm{mg} / \mathrm{L}$ $\mathrm{Fe}(\mathrm{II})$ and $180 \mathrm{mg} / \mathrm{L}$ sulfate] when the $\mathrm{H}_{2}$ concentrations were characteristic of sulfate reduction. These data suggest increased $\mathrm{Fe}$ (II) production during the time of probable Fe(III) reduction (September 1999) and increased sulfate consumption during the time of probable sulfate reduction (January-February 2000). The small amount of sulfide present in September 1999 , despite the $\mathrm{H}_{2}$ concentrations in the $\mathrm{Fe}(\mathrm{III})$ reducing range, may reflect sulfide transport or the presence of sulfate reduction in localized zones, or aquifer microzones. Sulfide was not analyzed during the January-February 2000 sampling.

One possible explanation for the apparent shift from iron reduction to sulfate reduction at well 1-NECMW34-P is the depletion of bioavailable Fe(III). It is unlikely, however, that the microorganisms that had been operating under Fe(III)-reducing conditions for the duration of the ground-water contamination existence (which may have been since the 1940s) coincidentally depleted the bioavailable Fe(III) during the 4 months separating the sampling events. More probable is that the TEAP shift represents a cyclic occurrence similar to that observed elsewhere (Vroblesky and Chapelle, 1994) where anaerobic ground water having dissolved $\mathrm{Fe}$ (II) and under sulfate-reducing or methanogenic conditions undergoes an oxidation event. The source of the oxidation could be from oxygenated rainwater infiltration. The DO may be partly or completely scavenged by chemical reaction with dissolved $\mathrm{Fe}(\mathrm{II})$ and subsequent precipitation of $\mathrm{Fe}(\mathrm{III})$ as grain coatings. This $\mathrm{Fe}(\mathrm{III})$ is then available to support iron reduction. The TEAP can then shift back to iron reduction as the iron-reducing bacteria out-compete the methanogens or sulfate reducers for available substrate. Thus, these data suggest that the overburden aquifer at well 1-NEC-MW34-P is subject to oxidation events by oxygenated rainwater infiltration. As will be shown, this may have important consequences on the biodegradation potential of the aquifer sediments.

Evidence that ground water in the northeastern part of the station exhibited a stratification of aerobic/ anaerobic TEAP conditions during September 1999 can be seen at well 1-NE-MW23-P, where the DO content was $0.7 \mathrm{mg} / \mathrm{L}$ after purging 2 gal of water from the well and was $2.5 \mathrm{mg} / \mathrm{L}$ approximately 20 minutes later after purging 4 gal (table 3 ) from the well. Because the saturated interval sampled by the well was only $5.19 \mathrm{ft}$ thick, this observation suggests that the water initially pumped from the well represented a layer of anaerobic water beneath aerobic water. Supporting evidence for this hypothesis is the black staining observed on the bottom few inches of weighted rope that had been in the well as a support line for passive diffusion bag samplers. The simplest explanation for the black staining is that it results from sulfide precipitation during sulfate reduction in the lower part of the well. Further evidence for the presence of aerobic water overlying anaerobic water, or a temporal mixing of anaerobic and aerobic zones, is suggested by the fact that the USGS measurements by diffusion sampling and by low-volume purging showed anaerobic ground water at well 1-NEC-NW34-P in September 1999 (table 3), whereas the three-casing-volume purge approach used by the station consultant in JanuaryFebruary 2000 showed aerobic conditions (table 4).

Methane also was present in ground water from well 1-NE-MW23-P and from most of the tested wells in the overburden aquifer. These data suggest the occurrence of methanogenesis. The fact that the overburden aquifer contains high concentrations of sulfate (39-980 $\mathrm{mg} / \mathrm{L}$ ) and $\mathrm{H}_{2}$ concentrations characteristic of $\mathrm{Fe}(\mathrm{III})$ or sulfate reduction indicates that $\mathrm{Fe}$ (III) and sulfate reduction are predominant TEAPs in the overburden aquifer. However, the poorly permeable nature of the aquifer is conducive to the formation of methanogenic microzones in areas where the supply of electron donor is greater than the supply of sulfate and 
$\mathrm{Fe}(\mathrm{III})$. The relatively high concentration of total organic carbon (2.0-18.0 $\mathrm{mg} / \mathrm{L}$; table 4) in ground water from the overburden aquifer is consistent with the hypothesis of methanogenic conditions in aquifer microzones.

Other potential sources of methane in the overburden aquifer include diffusion of methane from methanogenic zones in the underlying shale or in the bedrock aquifer beneath the shale. Methane is present in the bedrock aquifer below the shale and may be a source for the methane in the overburden aquifer if a migration pathway through the shale is available. The shale is highly competent and probably does not allow substantial vertical movement of solutes in the northeastern part of the station; however, previous excavations, such those as near buildings F, G, and E, thinned or breached the shale layer.

The ground-water samples from the bedrock aquifer were anaerobic, and the implied predominant TEAP ranged from sulfate reduction to methanogenesis. The $\mathrm{H}_{2}$ concentration in ground water at well 1NE-MW23-S was $1.9 \mathrm{nM}$ as measured in the diffusion sampler and $1.0 \mathrm{nM}$ as measured by the bubble-strip method (table 3). These $\mathrm{H}_{2}$ concentrations are in the range characteristic of sulfate reduction. Sulfate $(24.7-26.3 \mathrm{mg} / \mathrm{L})$ and sulfide $(0.5 \mathrm{mg} / \mathrm{L})$ were present in water from the well, supporting the hypothesis that sulfate reduction was the predominant TEAP. However, methane was present in samples from both $25 \mathrm{ft}$ and $45 \mathrm{ft}$, suggesting that there is a mixture of TEAPs (sulfate reduction and methanogenesis) across the 20-ft-long screened interval of this well. Although no $\mathrm{H}_{2}$ sample was collected from well 1-NEC-MW17-S, high concentrations of sulfate $(267.7 \mathrm{mg} / \mathrm{L})$ and the presence of sulfide $(0.6 \mathrm{mg} / \mathrm{L})$ and methane $(41.2 \mathrm{mg} / \mathrm{L})$ suggest that both sulfate reduction and methanogenesis are active in the screened interval or upgradient from that well.

At well 1-NW-MW24-S in the bedrock aquifer, the $\mathrm{H}_{2}$ concentrations were $32 \mathrm{nM}$ as measured in the diffusion sampler and $22 \mathrm{nM}$ as measured by the bubble-strip method. This well contained methane (89.8-128.2 $\mathrm{mg} / \mathrm{L})$ and sulfate concentrations ranging from undetectable at $30 \mathrm{ft}-16.6 \mathrm{mg} / \mathrm{L}$ at $25 \mathrm{ft}$ depth. These data suggest that methanogenesis is the predominant TEAP in ground water at well 1-NW-MW24-S.

The fact that other tested wells in the bedrock aquifer contained sulfate concentrations ranging from 16.6-267.7 mg/L, suggests that parts of the bedrock aquifer contain sufficient sulfate to allow sulfate reduction to out-compete methanogenesis. Because acetate accumulation is more commonly observed under methanogenic conditions than under less reducing conditions, the presence of acetate in some bedrock wells in addition to sulfate suggests there is a layering of methanogenesis in the aquifer or that the acetate was generated elsewhere and transported to the well (Vroblesky and others, 1996). The low flow rates in these wells, however, argue for a local source, supporting the hypothesis of layered or heterogeneous distribution of methanogenesis and sulfate reduction within the bedrock aquifer.

\section{Biodegradation Potential of Chlorinated Solvents at the Station}

Chlorinated ethenes may be biodegraded in the subsurface by a variety of mechanisms that include anaerobic reductive dechlorination, aerobic (methylotrophic) cometabolic oxidation, and direct oxidation under aerobic and anaerobic conditions. As will be shown, reductive dechlorination of chlorinated solvents is almost certainly taking place in the overburden aquifer in the northeastern part of the station. In addition, the apparent layering or heterogeneous distribution of TEAPs suggests the possibility that oxidative processes also may play an important role in chlorinated solvent degradation at the station. The potential for these mechanisms to actively degrade the chlorinated solvents at the station is examined in the following sections.

\section{Reductive Dechlorination of Chlorinated Solvents}

Tetrachloroethene is readily degraded by reductive dechlorination in anaerobic systems (Vogel and others, 1987), and trichloroethene reductive dechlorination can occur under iron-reducing or more reducing conditions (Vogel and others, 1987); however, the less chlorinated daughter products, DCE and VC, commonly accumulate because the tendency to undergo reductive dechlorination decreases with decreasing number of chlorine atoms (Vogel and others, 1987; Bouwer, 1994; McCarty and Semprini, 1994; Vogel, 1994). Reductive dechlorination of cis-1,2-DCE apparently requires sulfate-reducing or methanogenic conditions (Vogel and others, 1987; Chapelle, 1996). Vinyl chloride reductive dechlorination appears to be slow and only significant under methanogenic conditions (Vogel and McCarty, 1985; Barrio-Lage and others, 1987; Freedman and Gossett, 1989; DiStefano and 
others, 1991; De Bruin and others, 1992; Carter and Jewell, 1993; Bouwer, 1994; Ballapragada and others, 1995; Fennell and others 1995; Maymo-Gatell and others 1995; Odum and others, 1995; Wu and others, 1995).

Microbial reductive dechlorination can result from an anaerobic cometabolism brought about by the accidental interaction of chloroethenes with enzymes and cofactors produced by microorganisms for other metabolic purposes (McCarty and Semprini, 1994). This type of cometabolic dechlorinating process is considered ubiquitous in anaerobic systems, but generally incapable of mediating complete reduction to nontoxic products like ethane (Bradley, 2000). In addition, reductive dechlorination can be carried out by halorespiring bacteria that are capable of growing using chloroethenes as sole terminal electron acceptors (Hollinger and others, 1993; Krumholz and others, 1996; Sharma and McCarty, 1996; Maymo-Gatell and others, 1997). One microbe, Dehalococcus ethenogenes, has been shown to completely degrade PCE to ethene (Maymo-Gatell and others, 1997). However, competition for electron donors, $\mathrm{H}_{2}$ and possibly formate and acetate, by respiring bacteria and homoacetogens probably limits the effectiveness of this degradation mechanism for chlorinated ethenes (McCarty, 1996; Smatlak and others, 1996; Bradley, 2000).

The presence of reduced daughter products in the overburden ground water at the station strongly suggests that microbial reductive dechlorination of PCE and TCE is significant in the overburden aquifer. In ground water in the northeastern part of the station at well 1-NEC-MW34-P, the high concentrations of cis-1,2-DCE (6,500-28,000 $\mu \mathrm{g} / \mathrm{L}), \mathrm{VC}(510-890 \mu \mathrm{g} / \mathrm{L})$ (table 2), ethane (approximately 4,800 $\mathrm{ng} / \mathrm{L}$ ) and ethene (approximately 39,000 ng/L) (table 4) indicate that substantial dechlorination has occurred. The presence of apparent daughter products, 1,2-DCE and VC in other wells (1-NE-MWT8-P, 1-NEC-MW15-P, 1-NE-MW23-P; 1-NEC-MW9-P) in the northeastern and north central parts of the station provide supporting evidence of the significance of reductive dechlorination in the overburden aquifer.

Unlike the northeastern part of the station, the contaminated ground water at well 1-NW-MW24-P in the northwestern part of the station shows little evidence of reductive dechlorination. Although PCE $(19-69 \mu \mathrm{g} / \mathrm{L})$ and TCE $(8.3-17 \mu \mathrm{g} / \mathrm{L})$ were present in the ground water at well 1-NW-MW24-P, the ground water contained no detectable VC or 1,2-DCE isomers (table 2).
Moreover, the ethane and ethene concentrations at well 1-NW-MW24-P were significantly lower than at wells with nondetectable contamination or at wells in the northeastern part of the station where reductive dechlorination appeared to be active (table 4). These data do not preclude reductive dechlorination at well 1-NWMW24-P. It is possible that the relative lack of reductive dechlorination daughter products reflect oxidative removal before they could accumulate. However, in the absence of evidence supporting reductive dechlorination at well 1-NW-MW24-P, the conservative conclusion is that reductive dechlorination processes at well 1-NW-MW24-P are not sufficient to naturally attenuate the chlorinated solvents.

\section{Oxidation of Chlorinated Solvents}

A variety of oxidation mechanisms can result in decreased concentrations of chlorinated solvents. Oxidation can occur under aerobic or anaerobic conditions. The data suggest that some of these processes may play a significant role in contaminant degradation in the northeastern part of the station.

The apparent presence of stratified aerobic/ anaerobic conditions during the September 1999 sampling event allows for intimate contact of the contaminants with a variety of redox conditions. Reductive dechlorination daughter products that degrade poorly under anaerobic conditions, may degrade rapidly under the adjacent aerobic conditions. Rapid microbial degradation of $\mathrm{VC}$ and microbial use of $\mathrm{VC}$ as a primary substrate can take place under aerobic conditions (Hartmans and deBont, 1992; Davis and Carpenter, 1990; Phelps and others, 1991; Hartmans and others, 1985; Bradley and Chapelle, 1996, 1998a, 1998b, Bradley and others, 1998b). Microbial oxidation of DCE also can be rapid and can occur without addition of carbon substrate under aerobic conditions (Bradley and Chapelle, 1998b; Bradley and others, 1998b, 1998c; Klier and others, 1999; Bradley and Chapelle, 2000a).

Anaerobic microbial oxidation of DCE and VC also can be significant under some conditions (Bradley, 2000). Anaerobic VC oxidation can be significant under iron-reducing and sulfate-reducing conditions (Bradley and Chapelle, 1998b) that characterize the anaerobic zone of the overburden aquifer at the station. Thus, it appears that conditions at the station sometimes are favorable for VC degradation under Fe(III)reducing conditions. For example, under Fe(III)-reducing conditions at well 1-NEC-MW34-P between September 
1999 and January-February 2000, the increase in the TCE/VC ratio (from 0.1-0.3) suggests a loss of VC relative to TCE, despite the apparent production of dechlorination daughter product, as evidenced by the decrease in the TCE/cis-1,2-DCE ratio (from 0.8-0.3).

Vinyl chloride also can be degraded under methanogenic conditions by fermentative acetogenesis (Bradley and Chapelle, 1998a; 1998b; 2000b). Both VC and DCE can be oxidized when coupled to humicacid reduction (Bradley and others, 1998a); however, it is not clear whether these processes are important contaminant-removal processes at the station.

Finally, cometabolic oxidation may be an additional important biodegradation mechanism at the station. Cometabolic oxidation is a highly efficient degradation process in which aerobic bacteria oxidize TCE, DCE, and VC to carbon dioxide under aerobic conditions without accumulation of intermediates (Wilson and Wilson, 1985; McCarty and Semprini, 1994). In this process, microorganisms contain nonspecific enzymes that fortuitously oxidize chloroethenes to carbon dioxide in the presence of oxygen, and a primary substrate that initiates oxygenase production. An example would be TCE degradation by methanotrophic bacteria (McCarty and Semprini, 1994).

Cometabolic oxidation requires specific restrictive conditions that probably are not often met under typical field conditions but seem to occur at the station. To be effective, cometabolic oxidation requires the chlorinated solvents to be in contact with a readily oxidizable organic compound, such as methane, and to be in an aerobic environment (Vogel and others, 1987). Because these conditions are rarely achieved in the field except at plume fringes, by engineering, or possibly at ground-water/surface-water interfaces in streams and lakes (Dolan and McCarty, 1995; Anderson and McCarty, 1997; Bradley and Chapelle, 1997; Bradley, 2000), such degradation probably is not a widespread process in many plumes. Conditions in the overburden aquifer at the northeastern part of the station, however, appear to be uniquely favorable to methylotrophic cometabolic oxidation of chlorinated solvents. The aquifer in that area is thin (about 3-5 ft) and seems to contain anaerobic water overlain by a veneer of oxygenated water. There also seems to be a significant supply of methane from local production or from diffusion through the underlying shale layer.
To obtain a direct measurement of the ability of overburden aquifer microbes to degrade TCE by methylotrophic cometabolic oxidation, a laboratory investigation was conducted using material collected from the overburden aquifer at well 1-NEC-MW34-P, in the northeastern part of the station. The microbes in these sediments rapidly degraded TCE with no accumulation of daughter products. The final recovery of radiolabel as ${ }^{14} \mathrm{CO}_{2}$ was $38 \pm 6$ percent in unamended overburden microcosms and $90 \pm 8$ percent in methane-amended overburden microcosms (table 5, fig. 2). The fact that the final recovery of ${ }^{14} \mathrm{CO}_{2}$ was 20 percent or less in sterile controls and insignificant in sediment-free controls indicates that TCE oxidation was attributable to biological activity. The fact that the combined recovery of radioactivity as ${ }^{14} \mathrm{C}$-TCE and ${ }^{14} \mathrm{CO}_{2}$ was approximately 100 percent indicates that carbon dioxide was the sole product of TCE oxidation. The fact that the final recovery of $\left[1,2-{ }^{14} \mathrm{C}\right]$ TCE radiolabel as ${ }^{14} \mathrm{CO}_{2}$ was 2.4 times higher under methane-amended conditions (table 5, fig. 2) indicates that TCE oxidation was the result of methylotrophic cometabolic oxidation and that the rate of oxidation under in situ conditions probably is limited by the supply of methane.

Table 5. Final percentage recovery of carbon $14\left({ }^{14} \mathrm{C}\right)$ radiolabel in microcosms of overburden material from near well 1-NEC-MW34-P

[Data are means \pm standard deviations for triplicate experimental microcosms and duplicate control microcosms. Data are corrected for losses due to sampling. $\mathrm{CO}_{2}$, carbon dioxide; TCE, trichloroethene; \pm , plus or minus]

\begin{tabular}{llccc}
\hline \multirow{2}{*}{ Microcosm } & \multirow{2}{*}{ Treatment } & \multicolumn{3}{c}{${ }^{14}$ C-Recovery } \\
\cline { 3 - 5 } & & $\mathbf{C O}_{\mathbf{2}}$ & TCE & Total \\
\hline \multirow{2}{*}{ Unamended } & Experimental & $38 \pm 6$ & $51 \pm 7$ & $89 \pm 2$ \\
& Sterile sediment control & $20 \pm 2$ & $78 \pm 9$ & $97 \pm 7$ \\
& Sediment-free control & $0 \pm 0$ & $100 \pm 2$ & $100 \pm 2$ \\
Methane- & Experimental & $90 \pm 8$ & $9 \pm 10$ & $98 \pm 9$ \\
amended & Sterile sediment control & $11 \pm 5$ & $92 \pm 4$ & $102 \pm 6$ \\
& Sediment-free control & $0 \pm 0$ & $98 \pm 3$ & $98 \pm 3$ \\
\hline
\end{tabular}

These results demonstrate that the microbial community indigenous to the overburden aquifer at the station can degrade TCE to carbon dioxide by methylotrophic cometabolism and suggest that this process may contribute significantly to the attenuation of chlorinated solvents at the station. Methane production in the microcosms despite an aerobic headspace (data not shown), probably indicates that the poorly permeable 


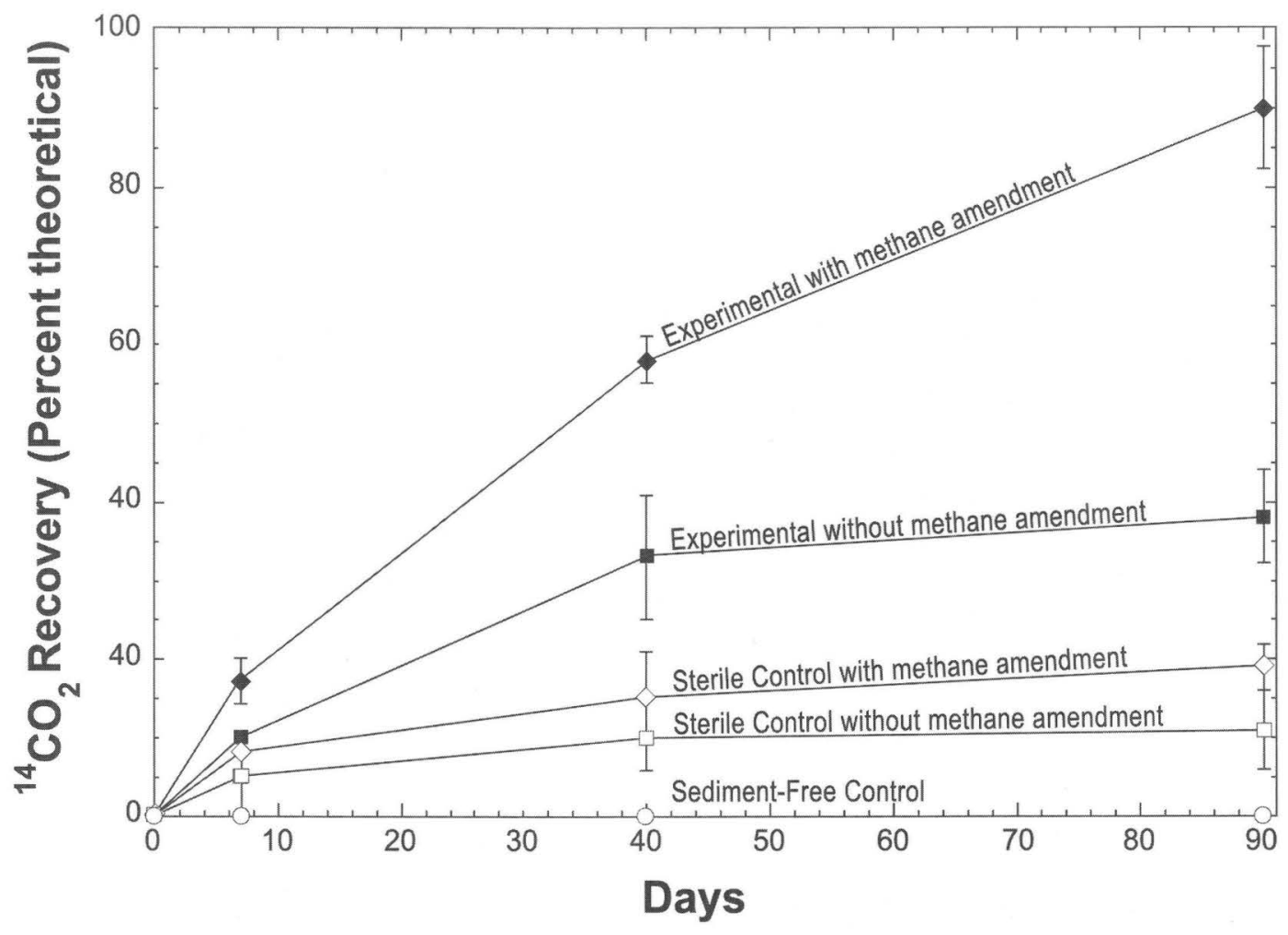

Figure 2. Percentage of carbon-14 radiolabeled carbon dioxide $\left({ }^{14} \mathrm{CO}_{2}\right)$ recovery in microcosms of sediment collected from the overburden aquifer near well 1-NEC-MW34-P, Naval Surface Warfare Center, Louisville, Kentucky, January 2000.

nature of the sediment allows methanogenesis to proceed in microzones unaffected by nearby aerobic conditions. These data suggest that a variety of mechanisms may be actively degrading the chlorinated solvents in the overburden aquifer in the northeastern part of the station. The mechanisms include reductive dechlorination, direct oxidation, and methylotrophic cometabolic oxidation.

These data also may have implications for the ground-water TCE contamination in the northeastern part of the station at well 1-NW-MW24-P. The lack of DCE and VC (table 2), the comparatively low concentrations of ethene and ethane (table 4), and the aerobic conditions (table 4) suggest that reductive dechlorination is not a significant contaminant-depletion process in the overburden aquifer at well 1-NW-MW24-P. Similarly, only trace methane $(0.11 \mathrm{mg} / \mathrm{L})$ was observed at well 1-NW-MW24-P. Thus, the probability that methylotrophic cometabolic oxidation is an important process at 1-NW-MW24P is less than at well 1-NEC-MW34-P. Finally, the dissolved inorganic carbon at well 1-NWMW24-P also is significantly lower $(285.3 \mathrm{mg} / \mathrm{L})$ than at the tested wells in the northeastern part of the station
(641.2-1,739.5 mg/L; table 3). Therefore, there is no compelling evidence to suggest that significant biodegradation of TCE is occurring in the overburden aquifer near well 1-NW-MW24-P.

\section{Potential for Chlorinated Solvent Biodegradation in the Bedrock Aquifer if Chlorinated-Solvent Contamination were to Enter the Aquifer}

Chlorinated solvents were not detected in ground-water samples from the bedrock aquifer. It is of interest, however, to know the potential of the aquifer to degrade chlorinated solvents if the contamination in the overburden aquifer were to leak through the shale into the underlying bedrock aquifer. Although the shale appears to be an effective barrier to downward chlorinated solvent migration in contaminated areas in the northern part of the station, there may be a concern for leakage where previous excavations have thinned or breached the shale layer, such as near buildings $\mathrm{F}, \mathrm{G}$, and E (Tetra Tech NUS, 2001). As will be shown, the redox conditions are favorable for chlorinated solvent degradation (sulfate reduction and methanogenesis), but laboratory microcosm experiments showed no potential for degradation, at least over the short term. 
A possible explanation for the apparent lack of biodegradation activity is that the microbial population, which had not previously been exposed to chlorinated solvents in the bedrock aquifer, may require an acclimation period to adapt to the chlorinated solvents.

Over a 100-day incubation period, no significant loss of TCE and no evidence of reductive dechlorination were observed in aquifer microcosms containing shale or limestone from downhole mesocosms (data not shown). Over a 48-hour incubation period, however, all aquifer microcosms containing mesocosm sediments demonstrated near complete (greater than 87 percent recovery of ${ }^{14} \mathrm{C}$-radiolabel as ${ }^{14} \mathrm{CO}_{2}$ ) mineralization of acetate. These results demonstrate that the microbial communities sampled by the mesocosms adjacent to the shale and bedrock aquifers at the station are metabolically active. Thus, the lack of significant TCE reduction observed in these aquifer materials is attributable to a specific lack of microbial reductive dechlorination ability rather than to a generally low level of metabolic activity.

The apparent lack of microbial reductive dechlorination activity in the shale and bedrock may be because the microbial population sampled by the mesocosms had not been previously exposed to chlorinated solvents. This may be partly a function of mesocosm placement during deployment. The mesocosms were deployed adjacent to the vuggy limestone zone in the bedrock aquifer, which, at the time was considered by previous site investigators to be a potentially conductive zone for contaminant transport. Subsequent investigation with a downhole colloidal borescope, however, showed that the vuggy zone in the bedrock aquifer does not effectively transport water (Aqua VISION, 1999). Thus, the microbes that populated the mesocosms may not have been collected from a bedrock zone where chlorinated solvents may once have been present.

These results suggest that if chlorinated solvents were to enter some parts of the bedrock aquifer, the microbial population would not immediately begin to degrade the contaminants. Because this laboratory investigation only examined the ability of microorganisms to reductively dechlorinate TCE over a short-term exposure (100 days), the potential for reductive dechlorination following an acclimation period cannot be ruled out. Moreover, because the mesocosms were deployed in poorly permeable horizons, the results may not be representative of more permeable parts of the bedrock aquifer.

\section{SUMMARY AND CONCLUSIONS}

The U.S. Geological Survey (USGS), in cooperation with the U.S. Department of the Navy, Southern Division, Naval Facilities Engineering Command, investigated the potential for biodegradation of chlorinated solvents in ground water at the Naval Surface Warfare Center (the station), Louisville, Kentucky. Ground-water contaminants at the station include chlorinated solvents and petroleum hydrocarbons, although most of the petroleum hydrocarbon contamination appears to be naturally occurring crude oil unrelated to station activities. Chlorinated-solvent contaminants at some locations along the northeastern edge of the station are thought to originate offsite. The remaining contaminants, with the possible exception of an area in the southwestern part of the station, probably are related to historical site activities, which include the manufacture and overhaul of weapons systems needed by combat vessels of the U.S. Navy.

In general terms, the subsurface down to at least $100 \mathrm{ft}$ at the station is characterized by three major lithologic rock types. From shallowest to deepest they are overburden deposits, a shale layer, and limestone. In general, all of the strata are poorly permeable. The water-bearing zones in the overburden deposits and the limestone are referred to as the overburden aquifer and the bedrock aquifer, respectively.

The predominant terminal electron-accepting processes (TEAPs) in anaerobic parts of the overburden aquifer appear to be sulfate reduction or iron reduction with limited methanogenesis occurring in poorly permeable microzones. The data suggest that at the time of sampling there was stratification of aerobic and anaerobic conditions and that the predominant anaerobic TEAP shifted between iron reduction and sulfate reduction, possibly as a result of oxidation events, such as rainfall. The predominant TEAPs in the bedrock aquifer probably are sulfate reduction and methanogenesis.

Biodegradation of chlorinated solvents seems to be active in parts of the station. Reductive dechlorination of chlorinated solvents apparently is taking place in the overburden aquifer in the northeastern part of the station. In addition, the presence of aerobic water overlying anaerobic water in the overburden aquifer, which has a saturated thickness of only about $3-5 \mathrm{ft}$ in many places at the station, allows for intimate contact of the contaminants with a variety of redox conditions.

This, in turn, suggests that cometabolic oxidation plays an important role in chlorinated solvent degradation at the station. Laboratory studies of overburden 
material from well 1-NEC-MW34-P, in the northeastern part of the station, showed that the sediments were capable of producing methane despite an aerobic atmosphere. Probably this was a result of the poorly permeable nature of the sediments that allowed methanogenesis to proceed in microzones unaffected by the aerobic atmosphere. In addition, the microbes in these sediments rapidly degraded TCE with no accumulation of daughter products. The fact that addition of methane to the treatment significantly enhanced TCE oxidation, indicates the degradation was the result of methylotrophic cometabolism and that the in situ rate of oxidation was limited by the supply of methane.

These data suggest that a variety of mechanisms may be actively degrading the chlorinated solvents in the overburden aquifer in the northeastern part of the station. The mechanisms include reductive dechlorination, direct oxidation and methylotrophic cometabolism.

These data may have implications for the ground-water TCE contamination in the northwestern part of the station at well 1-NW-MW24-P. The lack of DCE and VC and the comparatively low concentrations of ethene and ethane suggest that reductive dechlorination is not a significant contaminant-depletion process in the overburden aquifer at well 1-NWMW24-P. Similarly, the methane concentration at well 1-NW-MW24-P is significantly lower than at most wells in the northeastern part of the station, reducing the probability that cometabolic oxidation is an important process. Finally, the dissolved inorganic carbon at well 1-NW-MW24-P also is significantly lower than at the tested wells in the northeastern part of the station. These results imply that TCE is not being significantly biodegraded in the aquifer at well 1-NW-MW24-P.

Investigations using downhole mesocosms in the bedrock aquifer suggest that there is little or no shortterm potential for reductive dechlorination, despite the existence of geochemically favorable conditions. A possible explanation is that the microbial population, which had not previously been exposed to chlorinated solvents in the bedrock aquifer, may require an acclimation period to adapt to the chlorinated solvents. The data suggest that, if chlorinated solvents were to enter parts of the bedrock aquifer similar to the lowyielding zones sampled by the mesocosms, the microbial population would not immediately begin to degrade the contaminants. It is possible that degradation would proceed following an acclimation period or that the biodegradation potential would be greater in more permeable parts of the bedrock aquifer as compared to the horizons tested in this investigation.

\section{REFERENCES}

American Society for Testing and Materials, 1994, Standard test methods for low level dissolved oxygen in water: ASTM D-5543-94 Water Standards, p. 704-709.

Anderson, J.E., and McCarty, P.L., 1997, Transformation yields of chlorinated ethenes by a methanotrophic mixed culture expressing particulate methane monooxygenase: Applied Environmental Microbiology, v. 63, p. 687-693.

Aqua VISION, 1999, Colloidal borescope investigation at the Naval Ordnance Station, Crane Division, Naval Surface Warfare Center (NSWC), Louisville, Kentucky: Consultant's report to Southern Division Naval Facilities Engineering Command, May 19, 1999, 12 p.

Ballapragada, B.S., Puhakka, J.A., Stensel, H.D., Ferguson, J.F., 1995, Development of PCE transforming anaerobic cultures from municipal digester sludge, in Hinchee, R.E., Leeson, A., Semprini, L., eds, Bioremediation of chlorinated Solvents: Columbus, Ohio, Battelle Press, p. 91-97.

Barrio-Lage, G.A., Parsons, F.Z., Nassar, R.S., Lorenzo, P.A., 1987, Biotransformation of TCE in a variety of subsurface materials: Enviornmental Toxicology and Chemistry, v. 6, p. 91-97.

Bouwer, E.J., 1994, Bioremediation of chlorinated solvents using alternate electron acceptors, in Norris, R.D., and others, eds., Handbook of bioremediation, Boca Raton, Fla., Lewis Publishers, p. 149-175.

Bradley, P.M., 2000, Microbial degradation of chloroethenes in groundwater systems: Hydrogeology Journal, v. 8, p. 104-111.

Bradley, P.M., and Chapelle, F.H., 1996, Anaerobic mineralization of vinyl chloride in $\mathrm{Fe}(\mathrm{III})$-reducing aquifer sediments: Environmental Science and Technology, v. 30, p. 2084-2086.

1997, Kinetics of DCE and VC mineralization under methanogenic and $\mathrm{Fe}(\mathrm{III})$-reducing conditions: Environmental Science and Technology, v. 31, p. 2692-2696.

1998a, Effect of contaminant concentration on aerobic microbial mineralization of DCE and VC in streambed sediments: Environmental Science and Technology, v. 32, p. 553-557.

1998b, Microbial mineralization of VC and DCE under different terminal electron accepting conditions: Anaerobe, v. 4, p. 81-87.

2000a, Aerobic microbial mineralization of dichloroethene as sole carbon substrate: Environmental Science and Technology, v. 34, p. 221-223.

2000b, Acetogenic microbial degradation of vinyl chloride: Environmental Science and Technology, v. 34, p. 2761-2763. 
Bradley, P.M., Chapelle, F.H., and Lovley, D.R., 1998a, Humic acids as electron acceptors for anaerobic microbial oxidation of vinyl chloride and dichloroethene: Applied Environmental Microbiology, v. 64, p. 31023105.

Bradley, P.M., Chapelle, F.H., and Wilson, J.T., 1998b, Field and laboratory evidence for intrinsic biodegradation of vinyl chloride contamination in a $\mathrm{Fe}(\mathrm{III})$-reducing aquifer: Journal of Contaminant Hydrology, v. 31, p. 111-127.

Bradley, P.M., Landmeyer, J.E., and Dinicola, R.S., 1998c, Anaerobic oxidation of $\left[1,2-{ }^{14} \mathrm{C}\right]$ DCE under Mn(IV)reducing conditions: Applied Environmental Microbiology, v. 64, p. 1560-1562.

Carter, S.R., and Jewell, W.J., 1993, Biotransformation of tetrachloroetheylene by anaerobic attached-files at low temperatures: Water Research, v. 27, p. 607-615.

Chapelle, F.H., 1966, Identifying redox conditions that favor the natural attenuation of chlorinated ethenes in contaminated ground water systems: in Symposium on Natural Attenuation of Chlorinated Organics in Groundwater: Washington D.C., U.S. Environmental Protection Agency, EPA/540/R-96/509, p. 17-20.

Chapelle, F.H., and Lovley, D.R., 1990, Hydrogen concentrations in ground water as an indicator of bacterial processes in deep aquifer systems: in Proceedings of the First International Symposium on the Microbiology of the Deep Subsurface, U.S. Environmental Protection Agency, Orlando, Florida, p. 23.

1992, Competitive exclusion of sulfate reduction by Fe(III)-reducing bacteria: A mechanism for producing discrete zones of high-iron ground water: Ground Water, v, 30, p. 29-36.

Chapelle, F.H., and McMahon, P.B., 1991, Geochemistry of dissolved inorganic carbon in a Coastal Plain aquifer. Sulfate from confining beds as an oxidant in microbial $\mathrm{CO}_{2}$ production: Journal of Hydrology, v. 127 , p. $85-108$.

Chapelle, F.H., Vroblesky, D.A., Woodward, J.C., and Lovley, D.R., 1997, Practical considerations for measuring $\mathrm{H}_{2}$ concentrations in ground water: Environmental Science and Technology, v. 31, p. 2873-2877.

Davis, J.W., and Carpenter, C.L., 1990, Aerobic biodegradation of vinyl chloride in groundwater samples: Applied Environmental Microbiology, v. 56, p. 3870-3880.

De Bruin, W.P., Kotterman, M.J.J., Posthumus, M.A., Schraa, G., Zehnder, A.J.B., 1992, Complete biological reductive transformation of PCE to ethane: Applied Envionmental Microbiology, v. 58, p. 1966-2000.
DiStefano, T.D., Gossett, J.M., Zinder, S.H., 1991, Reductive dechlorination of high concentrations of tetrachloroethene to ethene by an anaerobic enrichment culture in the absence of methanogenesis: Applied and Environmental Microbiology, v. 58, p. 2287-2292.

Dolan, M.E., and McCarty, P.L., 1995, Small-column microcosm for assessing methan-stimulated vinyl chloride transformation in aquifer samples: Environmental Science and Technology, v. 29, p. 1892-1897.

Environmental Liability Management, Inc., 1999, Hydrocarbon characterization, Naval Ordnance Station, Louisville, Kentucky: Letter report to Dave Olson, TetraTech NUS, Inc., Gaithersburg, Maryland, June 19, 1999, 3 p.

Fennel, D.E., Stover, M.A., Zinder, S.H., Gossett, J.M, 1995, Comparison of alternative electron donors to sustain PCE anaerobic reductive dechlorination, in Hinchee, R.E., Leeson, A., Semprini, L., eds., Bioremediation of Chlorinated Solvents: Columbus, Ohio, Battelle Press, p. 9-16.

Freedman, D.L., and Gossett, J.M., 1989, Biological reductive dechlorination of tetrachloroethylene and trichloroethylene to ethylene under methanogenic conditions: Applied and Environmental Microbiology, v. 55, p. 2144-2151.

Hach Company, 1992, Water analysis handbook: Loveland, Co, Hach Company, 831 p.

Hartmans, S., and deBont, J.A.M., 1992, Aerobic vinyl chloride metabolism in 0 Mycobacterium aurum L1:

Applied Environmental Microbiology, v. 58, p. 12201226.

Hartmans, S., deBont, J.A.M., Tramper, J., Luyben, K.C.A.M., 1985, Bacterial degradation of vinyl chloride: Biotechnology Letters, v. 7, p. 383-388.

Hollinger, C., Schraa, G., Stams, A.J.M, Zehnder, A.J.B., 1993, A highly purified enrichment culture couples the reductive dechlorination of tetrachloroethene to growth: Applied Environmental Microbiology, v. 59, p. 29912997.

Klier, N.J., West, R.J., Donberg, P.A., 1999, Aerobic biodegradation of dichlorethylenes in surface and subsurface soils: Chemosphere, v. 38, p. 1175-1188.

Kramer, Heribert, and Conrad, Ralf, 1993, Measurement of dissolved $\mathrm{H} 2$ concentrations in methanogenic environments with a gas diffusion probe: FEMS Microbial Ecology, v. 12, p. 149-158.

Krumholz, L.R., Sharp, R., Fishbain, S.S., 1996, A freshwater anaerobe coupling acetate oxidation to tetrachlorethylene dehalogenation: Applied Environmental Microbiology, v. 62, p. 4108-4113.

Lovley, D.R., and Goodwin, Steve, 1988, Hydrogen concentrations as an indicator of the predominant terminal electron-accepting reactions in aquatic sediments: Geochimica et Cosmochimica Acta, v. 52, p. 29933003. 
Maymo-Gatell, X., Chien, Y-T, Gossett, J.M., Zinder, S.H., 1997, Isolation of a bacterium that reductively dechlorinates tetrachloroethene to ethene: Science, v. 276, p. 1568-1571.

Maymo-Gatell, X., Tandoi, V., Gossett, J.M., Zinder, S.H., 1995, Characterization of an $\mathrm{H}_{2}$-utilizing enrichment culture that reductively dechlorinates tetrachloroethene to vinyl chloride and ethene in the absence of methanogenesis and acetogenesis: Applied Environmental Microbiology, v. 61, p. 3928-3933.

McCarty, P.L., 1996, Biotic and abiotic transformations of chlorinated solvents in ground water, in Symposium on Natural Attenuation of Chlorinated Organics in Groundwater: Washington D.C., U.S. Environmental Protection Agency, EPA/540/R-96/509, p. 5-9.

McCarty, P.L., and Semprini, L., 1994, Groundwater treatment for chlorinated solvents, in Norris, R.D., and others, eds., Handbook of bioremediation, Boca Raton, Fla., Lewis Publishers, p. 87-116.

Microseeps, 2000, Hydrogen sampling instructions: Accessed June 29, 2001, at URL http://www.microseeps.com/.

Odum, J.M., Tabinowski, J., Lee, M.D., and Fathepure, B.Z., 1995, Anaerobic biodegradation of chlorinated solvents: Comparative laboratory study of aquifer microcosms, in Norris, R.D., and others, eds., Handbook of bioremediation, Boca Raton, Fla., Lewis Publishers, p. 17-24.

Phelps, T.J., Malachowsky, K., Schram, R.M., and White, D.C., 1991, Aerobic mineralization of vinyl chloride by a bacterium of the order Actinomycetales: Applied Environmental Microbiology, v. 57, p. 1252-1254.

Sharma, P.K., and McCarty, P.L, 1996, Isolation and characterization of a facultatively aerobic bacterium that reductively dehalogenates tetrachloroethene to $\mathrm{cis}$-1,2dichloroethene: Applied Environmental Microbiology, v. 62 , p. $761-765$.

Smatlak, C.R., Gossett, J.M., Zinder, S.H., 1996, Comparative kinetics of hydrogen utilization for reductive dechlorination of tetrachloroethene and methanogenesis in an enrichment culture: Environmental Science and Technology, v. 30, p. 2850-2858.
Tetra Tech NUS, Inc., 2001, RCRA Facility Investigation, Naval Ordnance Station Crane Division, Naval Surface Warfare Center, Louisville, Kentucky: Consultant's report to Southern Division Naval Facilities Engineering Command, v. 1, book 2, $176 \mathrm{p}$.

U.S. Environmental Protection Agency, 1999, On-line SW-846 methods: Accessed December 21, 1999, at URL www.epa.gov/epaoswer/hazwaste/test/tx8xxx. htm\#8XXX.

Vogel, T.M., 1994, Natural bioremediation of chlorinated solvents, in Norris, R.D., and others, eds., Handbook of bioremediation, Boca Raton, Fla., Lewis Publishers, p. 201-225.

Vogel, T.M., Criddle, C.S., McCarty, P.L., 1987, Transformations of halogenated aliphatic compounds: Environmental Science and Technology, v. 21, p. 722-736.

Vogel, T.M., and McCarty, P.L., 1985, Biotransformation of tetrachloroethylene to trichloroethylene, dichloroethylene, vinyl chloride, and carbon dioxide under methanogenic conditions: Applied Environmental Microbiology, v. 49 , p. $1080-1083$.

Vroblesky, D.A., Bradley, P.M., and Chapelle, F.H., 1996, Influence of electron donor on the minimum sulfate concentration required for sulfate reduction in a petroleum hydrocarbon-contaminated aquifer: Environmental Science \& Technology, v. 30, no. 4, p. 137-1381.

Vroblesky, D.A., and Chapelle, F.H., 1994, Temporal and spatial changes of terminal electron-accepting processes in a petroleum hydrocarbon-contaminated aquifer and the significance for contaminant biodegradation: Water Resources Research, v. 30, no. 5, p. 1561-1570.

Wilson, J.T, and Wilson, B.H., 1985, Biotransformation of trichloroethylene in soil: Applied Environmental Microbiology, v. 49, p. 242-243.

Wu, W.M., Nye, J., Hickey, R.F., Jain, M.K., and Zeikus, J.G., 1995, Dechlorination of PCE and TCE to ethene using an anaerobic microbial consortium: in Norris, R.D., and others, eds., Handbook of bioremediation, Boca Raton, Fla., Lewis Publishers, p. 42-52. 


\section{₹USGS VROBLESKY Biodegradation Potential Of Chlorinated Solvents In Ground Water At The Naval Surface Warfare Center,}

Louisville, Kentucky, July 1999 To February $2000 \quad$ USGS WRIR 01-4242 